\title{
Unlocking epigenetic codes in neurogenesis
}

\author{
Bing Yao and Peng Jin ${ }^{1}$ \\ Department of Human Genetics, Emory University School of Medicine, Atlanta, Georgia 30322, USA
}

\begin{abstract}
During embryonic and adult neurogenesis, neuronal stem cells follow a highly conserved path of differentiation to give rise to functional neurons at various developmental stages. Epigenetic regulation-including DNA modifications, histone modifications, and noncoding regulatory RNAs, such as microRNA (miRNA) and long noncoding RNA (IncRNA) - plays a pivotal role in embryonic and adult neurogenesis. Here we review the latest in our understanding of the epigenetic regulation in neurogenesis, with a particular focus on newly identified cytosine modifications and their dynamics, along with our perspective for future studies.
\end{abstract}

Neurogenesis generates various functional neural cell types from multipotent neural stem cells (NSCs) in the mammalian central nervous system (CNS), a process originally thought to occur only during embryonic development (Ming and Song 2005, 2011). The development of live cell labeling techniques, such as bromodeoxyuridine (BrdU) incorporation, has revolutionized our view on the spatial and temporal progress of neurogenesis by directly tracing different cell lineages in vivo /Gage 2000; Gotz and Huttner 2005; Lledo et al. 2006; Kriegstein and Alvarez-Buylla 2009; Ming and Song 2011). It is now clear that neurogenesis is not restricted to the embryonic stage; adult neurogenesis takes place in particular zones of the mammalian brain throughout its life span and possibly correlates with complicated neuronal activities, such as learning and memory (Gage 2000; Gupta et al. 2002; Gotz and Huttner 2005; Ming and Song 2005, 2011; Lledo et al. 2006; Miller and Gauthier 2007; Kriegstein and AlvarezBuylla 2009; Okano and Temple 2009; Hsieh and Eisch 2010; Li and Jin 2010; Gage and Temple 2013).

The word "epigenetics" was first proposed by Waddington (1939) in the middle of the 20th century; the term is derived from the Greek words for "over" or "above" genetics to describe the molecular events involved in early undifferentiated embryonic development. Epigenetics is now broadly defined as the heritable changes in gene expression and function that do not alter DNA sequence (Holliday and

[Keywords: neurogenesis; epigenetics; DNA modifications; histone modifications; noncoding RNAs]

${ }^{1}$ Corresponding author

E-mail peng.jin@emory.edu

Article is online at http://www.genesdev.org/cgi/doi/10.1101/gad.241547.114.
Pugh 1975; Jaenisch and Bird 2003; Goldberg et al. 2007; Felsenfeld 2014). The vast majority of the cells in an organism share identical DNA sequence; however, precise epigenetic controls determine distinct cell types with stable gene expression profiles and phenotypes (Goldberg et al. 2007). Most epigenetic studies in the past decades focused on the covalent or noncovalent dynamic modifications of DNA and histone proteins and the impact of these modifications on transcription states. Recent work also introduced noncoding regulatory RNAs, such as microRNA (miRNA) and long noncoding RNAs (lncRNAs), as another layer of epigenetic regulation transcriptionally or post-transcriptionally (Bernstein and Allis 2005; Bartel 2009; Batista and Chang 2013). Both embryonic and adult neurogenesis share major principles and can be viewed as a classic case of stem cell differentiation processes ( $\mathrm{Ma}$ et al. 2010). In these processes, epigenetic modulations delicately orchestrate with extracellular environmental cues to determine the spatial and temporal expression of key regulators in neural stem/progenitor cells to control their proliferation, fate specification, and differentiation (Liu and Zhao 2009; Hsieh and Eisch 2010; Li and Jin 2010; Ma et al. 2010; MateusPinheiro et al. 2011; Pruunsild et al. 2011; Jobe et al. 2012).

In this review, we summarize the current knowledge of epigenetic regulation in neurogenesis. We begin by describing various aspects of embryonic and adult neurogenesis and their potential regulatory mechanisms. We then discuss the epigenetic modulations-including DNA modifications, histone modifications, and noncoding RNAs (ncRNAs)and their regulation of key steps of neurogenesis in vivo and in vitro. We focus in particular on the recently defined cytosine modification derivate for its roles in neurogenesis.

\section{Fundamentals of neurogenesis and regulatory mechanisms}

\section{Embryonic neurogenesis}

Embryonic neurogenesis in mice usually starts at embryonic day 8 (E8) and reaches its plateau around E14 (Fig. 1A;

(C) 2014 Yao and Jin This article is distributed exclusively by Cold Spring Harbor Laboratory Press for the first six months after the full-issue publication date (see http://genesdev.cshlp.org/site/misc/terms.xhtml). After six months, it is available under a Creative Commons License (AttributionNonCommercial 4.0 International), as described at http://creativecommons. org/licenses/by-nc/4.0/. 
A

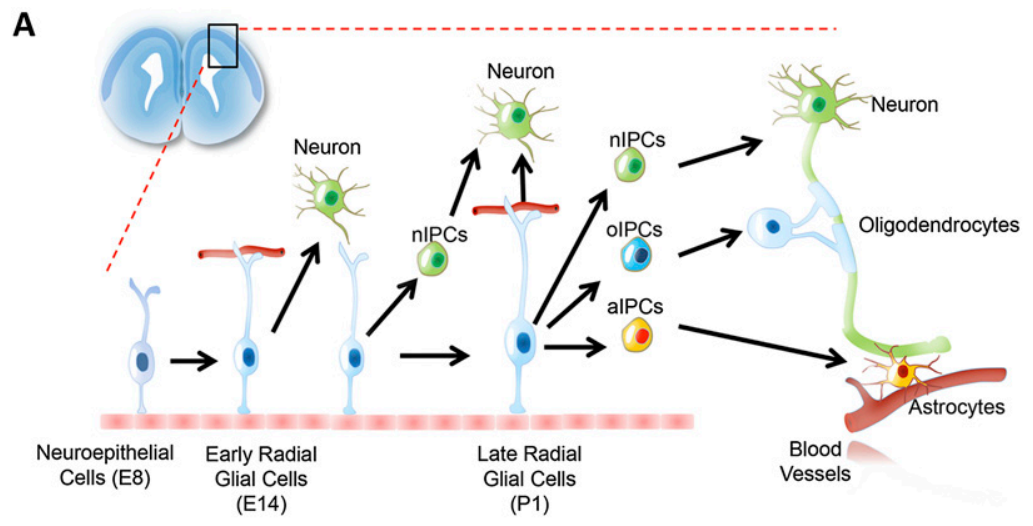

B

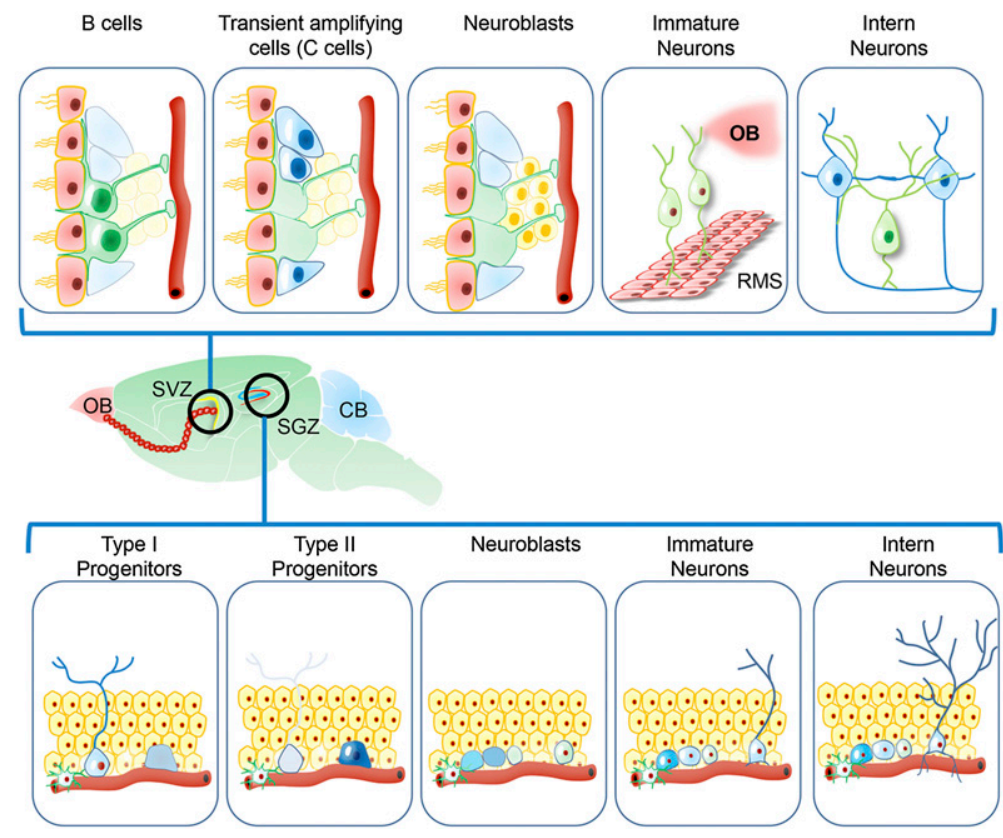

Figure 1. Embryonic and adult neurogenesis. (A) E14-E16 mouse brains, VZ, and SVZ harboring major neurogenesis activity are highlighted. Neuroepithelial cells are activated around E8 and develop into early RGs around E14. RGs can either give rise to neurons directly or generate nIPCs, which can be further differentiated into neurons. During development, RGs can also generate IPCs, which can differentiate into oIPCs and aIPCs. These intermediate progenitors can differentiate into their lineage destinies and eventually form a functional interneuron network. (B) Adult neurogenesis in the subgranular zone (SGZ). Quiescent RGs, also called B cells, become activated upon adult neurogenesis and produce transit amplifying cells (also termed C cells). C cells generate neuroblasts, which undergo a maturation process by migrating through the rostral migratory stream (RMS) and become interneurons in the olfactory bulb (OB). RGs (also known as type I progenitors) in the dentate gyrus (DG) give rise to nIPCs (referred to as type II progenitors or D cells). Immature type II progenitors migrate to the inner granule cell (GC) layers and differentiate into neuroblasts. Neuroblasts become immature neurons and undergo synaptic integration to merge into the existing circuitry.
$\mathrm{Li}$ and Jin 2010). At E8-E10, the neuroepithelial cells located within the ventricular zone (VZ) and subventricular zone (SVZ) start undergoing transformation, acquire astroglial properties, and are hence termed "radial glial" cells (RGs) due to their spatial and morphological arrangements (Fig. 1A; Gotz and Huttner 2005; Kriegstein and Alvarez-Buylla 2009). RGs possess fate-restricted NSC features that can either directly generate nascent neurons or produce intermediate neuron progenitor cells (nIPCs), which can then differentiate into neurons through symmetrical mitosis (Huttner and Brand 1997; Campbell and Gotz 2002; Haubensak et al. 2004; Noctor et al. 2004). In either case, RGs go through asymmetrical division to maintain their self-renewal properties. Meanwhile, RGs can also participate in gliogenesis by producing intermediate progenitor cells (IPCs) for an astrocyte or oligodendrocyte destiny (aIPCs or oIPCs, respectively). During this process, self-renewing RGs are anchored on both the pial and ventricular surfaces, contacting blood vessels to ensure the necessary nutrient supply and extracellular signaling transduction. Newly synthesized neurons and glial cells are continuously migrating toward the cortex during embryonic development, thickening the neocortex and forming an interneuron network. At the end of embryonic development, most RGs come loose from their ventricular attachment and migrate toward the cortical plate. There, most RGs transform into astrocytes and conclude the process of embryonic neurogenesis around the neonatal stage (postnatal day 1 [P1]). However, a number of residual RGs remain quiescent in the SVZ region and are responsible for adult neurogenesis (Fig. 1A; Gotz and Huttner 2005; Kriegstein and Alvarez-Buylla 2009).

RGs hold both neuroepithelial and glial properties by coexpressing their signature markers. For example, a number of intermediate filament proteins, such as Nestin and Vimentin, are present as neuroepithelial markers in RGs. Meanwhile, some astroglial markers-among them the astrocyte-specific glutamate transporter (GLAST), brain lipid-binding protein (BLBP), and glial fibrillary acidic protein (GFAP) - are also expressed in RGs (Hartfuss et al. 2001; Mori et al. 2005). The epithelial features of RGs may be responsible for maintaining their apical-basal polarity, which is important for nascent neuron migration (Noctor et al. 2001). The RGs are tightly attached to the apical 
surface through adherens junctions to maintain their multipotency (Kriegstein and Alvarez-Buylla 2009). On the other hand, the expression of glial markers in RGs is associated with their neurogenic specificity. The expression of these markers is subject to precise epigenetic regulation. In addition, it appears that the RGs are highly heterogeneous, serving as fate-restricted progenitors with the ability to differentiate into various neural subtypes in both embryonic and adult neurogenesis (Kriegstein and Alvarez-Buylla 2009; Ming and Song 2011). Both identity and differentiation potential are determined by the orchestration between extracellular signals-such as Notch, bone morphogenetic proteins (BMPs), Wnt/ $\beta$-catenin, and Sonic hedgehog (SHH) (Maier et al. 2011; Imayoshi et al. 2013) - and intrinsic regulators (such as transcription factors) (Long et al. 2009) as well as epigenetic modifiers (Hsieh and Eisch 2010; Jobe et al. 2012; Pattaroni and Jacob 2013). Many of these transcription factors, like Pax6 (Balmer et al. 2012) and Dlx2 (Lim et al. 2009), are heavily controlled by distinct epigenetic modulations, such as promoter DNA/histone modifications or post-transcriptional regulation by ncRNAs. The detailed epigenetic mechanisms involved in both embryonic and adult neurogenesis are discussed below.

\section{Adult neurogenesis}

Adult neurogenesis occurs mainly in two specific regions of the adult brain: the SVZ and subgranular zone (SGZ) of the hippocampal dentate gyrus (DG) (Fig. 1B; Gage 2000; Ming and Song 2005, 2011; Lledo et al. 2006; Kriegstein and Alvarez-Buylla 2009; Hsieh and Eisch 2010; Gage and Temple 2013). The adult SVZ, a region closely related to the embryonic SVZ, where embryonic neurogenesis takes place as described, harbors postnatal RGs that are relatively quiescent and known as B cells. Upon adult neurogenesis in the SVZ, B cells first give rise to transient amplifying cells (also termed C cells), which function as the nIPC. C cells can then differentiate into neuroblasts (A cells), which become immature/migrating neurons that travel in chains to the olfactory bulb (OB) through the rostral migratory stream (RMS). The immature neurons convert to their mature form in the OB by differentiating into different subtypes of local interneurons (Gage 2000; Lledo et al. 2006; Kriegstein and Alvarez-Buylla 2009; Ming and Song 2011). It has been suggested that $>30,000$ neuroblasts exit the rodent SVZ for the RMS each day, indicating that there is vigorous neurogenic activity in the SVZ on a daily basis (Alvarez-Buylla et al. 2001).

Another major region that generates nascent neurons in the adult mammalian brain is the DG of the hippocampus (Gage 2000; Lledo et al. 2006; Kriegstein and Alvarez-Buylla 2009; Ming and Song 2011). Similar to embryonic and adult neurogenesis in the SVZ, radial astrocytes (also referred to as type I progenitors) in the SGZ work as primary NSCs in the DG (Fig. 1B; Filippov et al. 2003; Fukuda et al. 2003). Unlike RGs in embryonic neurogenesis, which can give rise directly to neurons, radial astrocytes in the SGZ produce nIPCs, referred to as type II progenitors or D cells (Filippov et al. 2003; Fukuda et al. 2003; Seri et al. 2004). Immature D cells migrate into the inner granule cell (GC) layer and differentiate into dentate GCs in the hippocampus (Ming and Song 2011). Finally, the nascent neurons will undergo synaptic integration and merge into the existing circuitry /Ge et al. 2008). It has been proposed that $\sim 9000$ new cells can be generated in young adult rats (Cameron and McKay 2001), playing a significant role in hippocampal function.

Both B cells in adult SVZ and type I progenitor cells retain some important properties of embryonic RGs, serving as bona fide NSCs in adult neurogenesis. For example, these cell types both express GFAP, GLAST, and other astroglial markers as well as stem cell markers, such as Nestin and Sox2 (Suh et al. 2007; Colak et al. 2008; Platel et al. 2009). In fact, the adult neurogenesis in both the SVZ and SGZ shares critical periods, such as the transition from intermediate progenitor to the neuroblast stage as well as the immature neuron integration stage (Tashiro et al. 2006; Platel et al. 2010). Both regions contain blood vessels adjacent to the NSCs and their progenies that deliver substantial extracellular signaling molecules to the vicinity of B cells and type I progenitor cells (Ming and Song 2005). Therefore, many intrinsic pathways and players that regulate SVZ- and SGZ-based neurogenesis, along with embryonic neurogenesis, are highly conserved. Nevertheless, the impact of extracellular elements, the neurogenic niche, and environment on neurogenesis in the SVZ and SGZ could be quite different (Lledo et al. 2006; Hsieh and Eisch 2010; Ming and Song 2011).

Intrinsic factors that determine NSC self-renewal and differentiation in neurogenesis are usually cell cycle regulators, transcription factors, and epigenetic factors (Zhao et al. 2008). As mentioned for embryonic neurogenesis, the intrinsic factors are subject to multiple layers of epigenetic regulation and are discussed later. The main extracellular elements influencing neurogenesis would be signal transducing morphogens, growth factors, neurotrophins, cytokines, and hormones (Lledo et al. 2006). For instance, as with embryonic neurogenesis, the SHH signaling pathway is required for progenitor cell maintenance, and loss of SHH results in a dramatic reduction of neural progenitor cells (NPCs) in both the SVZ and SGZ as well as abnormalities in the DG and OB. Stimulation of the SHH causes increased proliferation of progenitor cells (Machold et al. 2003). Ablation of the Notch receptor promotes rapid differentiation of NSCs into transient amplifying cells and neurons, resulting in the permanent loss of longterm neurogenesis (Imayoshi et al. 2010). In contrast, BMP inhibits neurogenesis and directs glial differentiation (Lim et al. 2000). These data suggest that neurogenic plasticity could be regulated by extracellular signaling.

Stem cells constantly interact with their microenvironment, which is defined as the "stem cell niche" (Li and Xie 2005). In both the SVZ and SGZ, the neurogenic niche consists of endothelial cells and astrocytes. Endothelial cells promote the self-renewal of NSCs by releasing vascular-derived factors (VEGFs) (Jin et al. 2002; Cao et al. 2004), whereas astrocytes direct NSCs to differentiate by releasing Wnt3, IL-1ß, and IL-6 (Lie et al. 2005; Barkho et al. 2006). Differentiated neurons can also participate in the feedback 
regulation of stem cell fate by releasing neurotransmitters such as GABA (Ge et al. 2006). These findings highlight the importance of a homeostatic neurogenic niche for proper neurogenesis. Environmental factors also contribute to neurogenesis. For example, physical exercise and an enriched environment promote cell proliferation and new neuron survival (Kempermann et al. 1997; van Praag et al. 2002). In the mouse OB and rat DG, learning influences the proliferation and survival of new neurons, depending on the age and specific learning phase in the mouse $\mathrm{OB}$ and rat $\mathrm{DG}$, thereby directly linking neurogenesis with learning and memory formation (Drapeau et al. 2007; Mouret et al. 2008).

Although neurogenesis in the SVZ and SGZ shares many similarities, it is different in several respects. Hippocampal neurogenesis is located solely in the DG, which is exposed to a dense neuronal environment and faces regulation from various neurotransmitters. The SVZ is segregated from the $\mathrm{OB}$, where mature neurons form an interneuron network (Ming and Song 2011). In addition, NSCs in the adult brain differ by location even though they originate from the same regions. For example, regional labeling of neonatal RG and adult SVZ B cells shows that NSCs originating from different location in the postnatal SVZ generate different types of OB interneurons (Merkle et al. 2004, 2007). Transcriptional factors, such as Pax6 or Sp8, are selectively expressed in a subpopulation of migrating neurons in the RMS (Hack et al. 2005; Waclaw et al. 2006). Taken together, these findings suggest that NSCs are regionally heterogeneous, programmed to express and determine different neuronal subtypes. Again, most of these transcription factors are undergoing tight epigenetic regulation and have led many scientists to explore the epigenetic aspects of neurogenesis.

Although adult neurogenesis occurs predominantly in the SVZ and SGZ, recent work suggests that it could also occur in other brain regions, including both the hypothalamus and striatum (Cheng 2013; Sousa-Ferreira et al. 2014). NSCs are present in the hypothalamus and can differentiate into neuropeptide-expressing neurons (Markakis et al. 2004). Hypothalamic neurogenesis was found to play an important role in energy balance (Kokoeva et al. 2005). Moreover, ciliary neurotrophic factor (CNTF)-induced weight loss in obese rodents could be attributed to neurogenesis in feeding centers of the murine hypothalamus; mitotic blockers eliminate this process and abrogate the long-term effects of CNTF (Kokoeva et al. 2005). Using genetic fate mapping, Lee et al. (2012) demonstrated that hypothalamic radial glia-like ependymal cells, known as tanycytes, are the NSCs in the ventral hypothalamic VZ. It appears that hypothalamic neurogenesis serves as a response center to physiological and pathological stimuli. On the other hand, targeted apoptotic degeneration of corticothalamic neurons can induce neurogenesis, raising the possibility that the striatum may also possess neurogenic ability (Magavi et al. 2000). Analysis in adult monkeys supports this hypothesis by showing that $\sim 5 \%-10 \%$ of newborn $\mathrm{BrdU}^{+}$striatal cells express the mature neuron marker neuronal nuclear antigen (NeuN) (Bedard et al. 2002). A very recent study confirms striatal neurogenesis in humans and, interestingly, shows that Huntington's disease (HD) patients display impaired neurogenesis in the striatum, a primary region affected by HD (Ernst et al. 2014). Given these findings, further investigation of the molecular regulatory mechanisms governing neurogenesis in the hypothalamus and striatum is warranted.

\section{Epigenetic regulation}

Neurogenesis involves various cell types with distinct properties. However, these cells share the same genome, being derived from the same zygote, emphasizing the key roles of epigenetic regulation in neurogenesis. Residing in the neurogenic niche, NSCs and their differentiated neural cells are exposed to a variety of extracellular and environmental cues. Nevertheless, it is obvious that these stimuli fulfill their functions by coordinating with an intracellular network and relying on transcription factors to activate or repress gene expression. During these steps, epigenetic modulations determine the DNA and histone accessibility of critical genes, fine-tune the expression of transcription factors or neurogenic genes, and shape the transcriptome landscape. Takahashi and Yamanaka (2006) identified four transcription factors that can reverse cell lineage commitment by turning fibroblasts into induced pluripotent stem cells (iPSCs), which recapitulate many features of embryonic stem cells (ESCs). These factors are permanently silenced epigenetically in fibroblasts, ensuring the correct cellular identity for fibroblasts (Stadtfeld and Hochedlinger 2010). In fact, epigenetic regulations in ESC and iPSC maintenance and differentiation have been well studied (Hemberger et al. 2009; Liang and Zhang 2013). In comparison, epigenetic regulation in mammalian neurogenesis has only emerged as a major focus in recent years (Hsieh and Eisch 2010; Ma et al. 2010; Mateus-Pinheiro et al. 2011; Sun et al. 2011b; Jobe et al. 2012; Pattaroni and Jacob 2013). Why do many epigenetic regulators possess dual roles in inhibiting and promoting neurogenesis? How does the dynamic plasticity of DNA modifications, especially the newly identified cytosine modification variants, impact the process of neurogenesis? The role of histone modifications in neurogenesis has been extensively studied over the past decade, and several excellent reviews have covered this topic in depth (Hsieh and Eisch 2010; Ma et al. 2010; Pereira et al. 2010; Sun et al. 2011b; Jobe et al. 2012). Given this and the rapid progresses toward understanding the dynamics of cytosine modifications made in recent years, we focus our discussion on the role of dynamic DNA methylation/demethylation in neurogenesis.

\section{DNA methylation}

\section{Cytosine methylation and DNA methyltransferases (DNMTs) in neurogenesis}

First described $>60$ years ago (Hotchkiss 1948), DNA methylation is one of the best-characterized cytosine covalent modifications; for decades, it remained the only known direct functional epigenetic modification on the 
genetic material (Goldberg et al. 2007). Methylation of the fifth position of cytosine $(5 \mathrm{mC})$ typically occurs in the context of regions that contain a high frequency of CG dinucleotides, termed CpG islands (CGIs), and plays a key role in the regulation of gene expression, chromatin structure, gene imprinting, chromosome inactivation, and genomic stability (Bird 1986; Jones and Baylin 2002; Goll and Bestor 2005; Suzuki and Bird 2008; Cedar and Bergman 2009; Smith and Meissner 2013). However, CGIs that are frequently located in gene promoters usually remain unmethylated. DNA methylation is typically associated with a gene-repressive environment by blocking transcription factors and machinery, recruiting methylcytosinebinding proteins and repressive histone modifiers (Cedar and Bergman 2009). DNA methylation is catalyzed by a family of three well-defined DNMTs that are responsible for preserving or generating $5 \mathrm{mC}$ on the genome (Bestor 2000). DNMT1 maintains DNA methylation during the cell cycle by copying the existing pattern of hemimethylated DNA to their daughter strands during mitotic S phase (Probst et al. 2009). Mechanistically, DNMT1 achieves its specificity by interacting with NP95 (also known as UHRF1), which binds preferentially to the hemimethylated DNA (Arita et al. 2008; Avvakumov et al. 2008; Hashimoto et al. 2008). In contrast, DNMT3a and DNMT3b act as de novo methyltransferases by transferring a methyl group from the universal methyl donor S-adenosyl-L-methionine (SAM) to the unmethylated cytosine in the genome (Bestor 2000). DNA methylation can be recognized and interpreted by a series of "readers," such as methyl-CpG-binding protein 2 (MeCP2) and methyl-CpG-binding domain proteins 1-4 (MBD1-4) (Hendrich and Bird 1998; Bogdanovic and Veenstra 2009).

DNA methylation has long been known to play a critical role in synaptic plasticity related to long-term learning and memory in mature neurons, possibly via regulation of specific gene expression (Miller and Sweatt 2007; Feng et al. 2010). The DNMTs are expressed differently in various stages and locations related to neurogenesis, indicating their distinct roles in this process. Dnmt 1 is ubiquitously expressed in both dividing neural precursor cells and post-mitotic neurons in mouse brains, in line with their role in maintaining DNA methylation patterns throughout cell replication (Goto et al. 1994). Dnmt3b is robustly expressed in the SVZ between E10.5 and E13.5, coinciding with vigorous embryonic neurogenesis (Fig. 1). Dnmt3b then gradually diminishes, becoming undetectable after E15.5 (Feng et al. 2005). In contrast, Dnmt3a starts to be expressed in the SVZ of NSCs from E10.5 to E17.5 and can be continuously detected predominantly in postnatal neurons from almost all brain regions (Feng et al. 2005).

Consistent with these observations, mutations in any of the three major Dnmts in mice lead to developmental abnormalities (Li et al. 1992; Okano et al. 1999); conditional knockout of Dnmts in mice was therefore needed to study their role in the CNS (Golshani et al. 2005; Nguyen et al. 2007; Wu et al. 2010). Dnmtl deletion in neuronal progenitor cells induces early derepression of astroglial marker genes, such as GFAP in the spinal cord.
DNA hypomethylation caused by the ablation of Dnmt1 activates the JAK-STAT astrogliogenic pathway and accelerates the glial differentiation process (Fan et al. 2005). Methyl-binding proteins, such as $\mathrm{MeCP} 2$, are found to bind and secure the methylation of glial gene promoters in early NPCs from wild-type animals and inhibit the premature expression of these genes (Fan et al. 2005). On the other hand, retinal NPCs with the loss of Dnmtl continue to proliferate but show ectopic cell cycle progression with accumulated G-phase cells. Post-mitotic neurons display defective terminal differentiation and result in rapid retinal degeneration (Rhee et al. 2012). These findings suggest multiple roles for Dnmt1 in regulating different steps of neurogenesis, possibly by modulating the methylation status of different subsets of genes.

Mice that lack functional Dnmt3a in the CNS appear to be grossly normal at birth but die prematurely with the acquisition of developmental defects, including hypoactivity and defective motor coordination (Nguyen et al. 2007). Wu et al. (2010) showed that Dnmt3a deletion impairs postnatal neurogenesis in both the SVZ and SGZ; 10-fold fewer neurons are differentiated from Dnmt3a-null NSCs. Genome-wide Dnmt3a occupancy and site-specific DNA methylation analyses in adult NSCs reveal that Dnmt3a methylates intergenic regions and gene bodies flanking proximal promoters of many neurogenesis-related genes, such as Dlx2, Neurog2, Sp8, and Gbx2. It is surprising that Dnmt3a not only mediates repression of self-renewing NSCs by methylating the promoter of key neural genes but also antagonizes repressive histone marker H3K27 trimethylation (H3K27me3) and its writer Polycomb (PcG) group proteins, indicating potential cross-talk between DNA methylation and histone modifications in neurogenesis (Wu et al. 2010). In a separate study, in vitro Dnmt3a-null NSCs derived from ESCs display precocious glial differentiation and enhanced proliferation (Wu et al. 2012). These data highlight the importance of Dnmt3a in neurogenesis and indicate that Dnmt3a works with other epigenetic factors to orchestrate a correct neurogenic path.

Although Dnmt3b is only expressed during a defined period in embryonic neurogenesis, it appears that methylation of certain differentiation markers in early stage NSCs by Dnmt3b is critical for maintaining their stemness. Knockdown of DNMT3b in neuroepithelium accelerated maturation (Martins-Taylor et al. 2012); however, retinoic acid could induce neuronal differentiation in embryonic carcinoma P19 cells, which led to the upregulation of Dnmt3b but the down-regulation of Dnmt1 and Dnmt3a. Increased Dnmt3b expression caused transcriptional repression of dipeptidyl peptidase 6 (Dpp6) by directly methylating its promoter. Moreover, the overexpression of Dpp6 or knockdown of Dnmt3b inhibited neuronal differentiation (Sheikh et al. 2013). These data imply that epigenetic regulation is precisely controlled in different cellular contexts.

\section{Methyl-CpG-binding proteins (MBPs) in neurogenesis}

MBPs are also indispensable for correctly interpreting existing methylation markers and critical for neurogen- 
esis. It has been shown that MBD1, which usually binds to hypermethylated promoters and regulates gene expression (Hendrich and Bird 1998), serves as a vital element in neurogenesis. MBD1 is expressed throughout the brain, with the highest concentration in the hippocampus (in both neurons and immature cells but not in astrocytes). In vitro cultured MBD1-null NSCs display impaired neurogenesis and increased genomic stability. MBD1 knockout mice show consistent impairment of neurogenesis and deficits in learning ability (Zhao et al. 2003). One explanation is that MBD1 can directly bind to the hypermethylated promoter of basic fibroblast growth factor 2 (Fgf2), an essential growth factor for neural development. The loss of MBD1 induces hypomethylation of the Fgf2 promoter and increases its expression in adult NSCs, which causes differentiation arrest (Li et al. 2008).

MeCP2 is another well-studied MBP since its discovery more than two decades ago (Lewis et al. 1992). Highly expressed in the brain, MeCP2 is known to regulate the maturation and proper function of the CNS (Shahbazian et al. 2002). MeCP2-deficient mice appear to be normal during early postnatal neurogenesis but show impaired neuronal maturation (Smrt et al. 2007). Transitioning neurons with DCX and NeuN double-positive are held up and fail to differentiate into more mature $\mathrm{NeuN}^{+}$/ $\mathrm{DCX}^{-}$neurons. As expected, the expressions of several genes related to synaptic development are found to be upregulated in the DG of MeCP2-deficient mice, among them Syndecan 2 and Prefoldin 5 (Smrt et al. 2007). One of the best-known MeCP2 targets is brain-derived neurotrophic factor (BDNF), which has been characterized extensively to regulate several aspects of neurogenesis, such as NSC proliferation and differentiation (Murray and Holmes 2011). The expression of BDNF is heavily regulated by promoter DNA methylation and is sensitive to Dnmt levels (Chen et al. 2003; Martinowich et al. 2003). MeCP2 physically occupies the hypermethylated BDNF promoter, and DNA demethylation in response to neuronal activity dissociates MeCP2 (Martinowich et al. 2003). On the other hand, MeCP2 is subjected to posttranslational modifications, such as phosphorylation on Ser421, changing its affinity to the BDNF promoter (Zhou et al. 2006). Recent genome-wide profiling of MeCP2 revealed that MeCP2 S421 phosphorylation occurs globally in response to neuronal stimulation and participates in dendritic development and key neurological responses (Cohen et al. 2011). MeCP2 misregulation leads to severe consequences, since individuals with overexpression or underexpression often develop neurodevelopmental disorders, including Rett syndrome and autism (Amir et al. 1999; Ramocki et al. 2009).

\section{DNA hydroxymethylation/demethylation}

DNA methylation was long viewed as a permanent and irreversible modification until the recent discovery that ten-eleven translocation 1 (TET1), a 2-oxoglutarate (2OG)dependent and Fe (II)-dependent enzyme, catalyzes conversion of $5 \mathrm{mC}$ to 5 -hydroxymethylcytosine $(5 \mathrm{hmC})$ (Kriaucionis and Heintz 2009; Tahiliani et al. 2009; Ito et al. 2010). Although controversial, the presence of $5 \mathrm{hmC}$ in the mammalian genome was initially reported more than two decades ago (Penn et al. 1972). Rao and colleagues (Iyer et al. 2009) applied in silico tools to search for the homolog of J-binding proteins (JBPs), which can oxidize the methyl group of thymine to generate 5hydroxymethyluracil (5hmU). The Tet family, including Tet1-3 in mammalian cells, was revealed because of a shared conserved catalytic domain with JBP (Pastor et al. 2013). Meanwhile, $5 \mathrm{hmC}$ was found by Kriaucionis and Heintz (2009) to be highly enriched in Purkinje neurons from mouse cerebella. This intriguing observation suggests a unique role for $5 \mathrm{hmC}$ in neuronal function. In fact, the level of $5 \mathrm{hmC}$ is $\sim 10$ times higher in various brain tissues, such as Purkinje neurons and DG in hippocampus (Kriaucionis and Heintz 2009; Munzel et al. 2010; Song et al. 2011; Szulwach et al. 2011b; Mellen et al. 2012), as well as ESCs than in other tissues (Ito et al. 2010; Pastor et al. 2011; Szulwach et al. 2011a; Yu et al. 2012). Subsequent studies went on to reveal that TET proteins can further oxidize $5 \mathrm{hmC}$ to 5 -formylcytosine $(5 \mathrm{fC})$ and 5 -carboxylcytosine $(5 \mathrm{caC})$, giving us a completely new perspective on the plasticity of $5 \mathrm{mC}$-dependent processes (Fig. 2; Ito et al. 2010, 2011; He et al. 2011). 5caC can be successively excised by thymine DNA glycosylase (TDG) to generate an abasic site, which can then be repaired to a cytosine by the base excision repair (BER) pathway (He et al. 2011; Ito et al. 2011; Pfaffeneder et al. 2011; Zhang et al. 2012). Based on these data, it becomes increasingly clear that cytosine modifications are highly dynamic, and active DNA methylation/demethylation could orches-

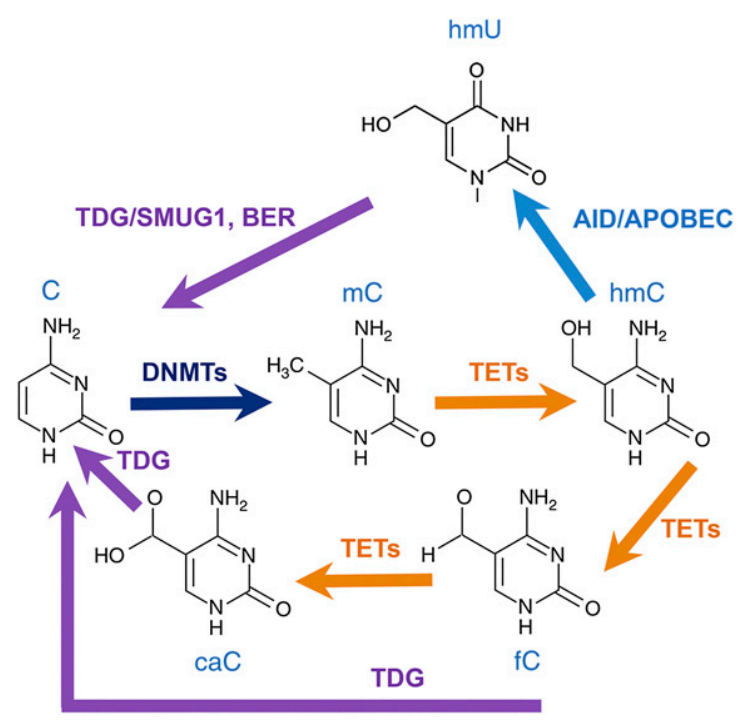

Figure 2. Dynamic DNA methylation/demethylation pathways. Cytosines (C) can be methylated by DNMTs into $5 \mathrm{mC}$. $5 \mathrm{mC}$ can then be oxidized into $5 \mathrm{hmC}$ by Tet proteins in a 2OGdependent and Fe (II)-dependent manner. Tet proteins can further oxidize the $5 \mathrm{hmC}$ to $5 \mathrm{fC}$ and $5 \mathrm{caC}$. Both $5 \mathrm{fC}$ and $5 \mathrm{caC}$ can be successively excised by TDG to generate an abasic site, which can be converted back to a cytosine by the BER pathway. 
trate with other epigenetic mechanisms to control gene expression.

The role of active DNA methylation/demethylation in neurogenesis was first suggested by the finding that Gadd45b (growth arrest and DNA damage-inducible protein $45 \mathrm{~b}$ ) is an early responder to various stimuli in the hippocampus, such as electroconvulsive treatment (ECT), and promotes adult neurogenesis (Ma et al. 2009). GADD45 family members have been implicated in active DNA demethylation in various systems (Barreto et al. 2007; Rai et al. 2008). Ma et al. (2009) showed that Gadd45b could induce promoter DNA demethylation of several genes involved in neurogenesis, including BDNF and Fgf. Gadd45b knockout mice demonstrated attenuated dendritic growth after ECT compared with wild type, indicating a key role for Gadd45b in active DNA demethylation during adult neurogenesis (Ma et al. 2009). However, whether GADD45-mediated DNA demethylation involves a TET-mediated hydroxylation/oxidation pathway remains to be determined.

\section{$5 \mathrm{hmC}$ in neurodevelopment and neurogenesis}

Recent genome-wide $5 \mathrm{hmC}$ profiling studies suggest that $5 \mathrm{hmC}$ has both a temporal and spatial distribution during neurodevelopment and aging (Song et al. 2011; Szulwach et al. 2011b; Mellen et al. 2012). Comparing 5hmC levels and distribution at different stages of postnatal neurodevelopment revealed an age-dependent acquisition of $5 \mathrm{hmC}$ in both the cerebellum and hippocampus. The acquisition of $5 \mathrm{hmC}$ in a number of neurodevelopmentally activated genes does not coincide with a concomitant loss of $5 \mathrm{mC}$, arguing that $5 \mathrm{hmC}$ is not solely a transient oxidation product of $5 \mathrm{mC}$ but rather is a stable modification that could play its own role in gene regulation in the brain (Szulwach et al. 2011b; Hahn et al. 2013). Furthermore, tissue-specific differentially hydroxymethylated regions (DhMRs) associated with different ages were identified. Intriguingly, the $>6000$ DhMRs that were found in the 6-wk-old, but not P7, cerebellum persist until 1 year of age, confirming that $5 \mathrm{hmC}$ serves as a stable and long-term epigenetic modification in the brain (Szulwach et al. 2011b). Mellen et al. (2012) took advantage of translating ribosome affinity purification (TRAP) coupled with a high-throughput sequencing technique to profile cell type-specific transcriptomes in mouse cerebella, including Purkinje cells (PCs), GCs, and the Bergmann glia (BG). Whole-genome $5 \mathrm{hmC}$ mapping was also conducted in specific cell types from fluorescence-activated cell sorting (FACS)-enriched nuclei. Although the exact correlation of $5 \mathrm{hmC}$ distribution with gene expression is still under debate, results clearly show that cell-specific active gene transcription coincides with enriched $5 \mathrm{hmC}$ and depleted $5 \mathrm{mC}$ on gene bodies (Mellen et al. 2012). Thus, the active role of $5 \mathrm{hmC}$ in regulating cell-specific gene expression may well explain the high abundance of $5 \mathrm{hmC}$ observed in the brain.

Emerging evidence suggests that dynamic cytosine modifications are involved in neurogenesis. Guo et al. (2011) demonstrated that $5 \mathrm{hmC}$ converted by TET 1 from
$5 \mathrm{mC}$ is more prone to undergo deamination than $5 \mathrm{mC}$ by the AID (activation-induced deaminase)/APOBEC (apolipoprotein B mRNA-editing enzyme complex) family of cytidine deaminases. The deamination product $5 \mathrm{hmU}$ triggers the BER pathway to be turned back to $5 \mathrm{mC}$ to complete the demethylation cycle (Guo et al. 2011). Overexpression of Tet1 or AID in the DG significantly decreased CpG methylation levels on two neuronal activityrelated genes, Bdnf and Fgf1b, but had no obvious effect on the promoter of nonneuronal genes, such as Fgf1G, which leads to differential gene activation.

$5 \mathrm{hmC}$ and chromatin remodeling during neurogenesis have also been examined recently (Hahn et al. 2013). Immunohistochemistry staining showed elevated $5 \mathrm{hmC}$ levels in differentiated neurons compared with adjacent NSCs in the SVZ during embryonic neurogenesis. Interestingly, no $5 \mathrm{mC}$ reduction is seen, consistent with the notion that $5 \mathrm{hmC}$ is a stable and independent epigenetic modification in the brain. The gain of $5 \mathrm{hmC}$ was largely on the neuronal gene body, with no evidence of substantial DNA demethylation, and was anti-correlated with repressive histone markers, such as H3K27me3. Overexpression of Tet3 and Tet2, two abundant Tet proteins in the embryonic cortex, induces early neuronal differentiation. There is a synergistic effect with simultaneous depletion of Ezh2, a PcG complex component and histone modifier responsible for adding H3K27me3. The inhibition of Tet proteins or overexpression of Ezh2 prevents differentiation. These loss-of-function and gain-of-function studies clearly demonstrate cross-talk between different epigenetic modifications and, most importantly, highlight a potential role for $5 \mathrm{hmC}$ in neurogenesis (Hahn et al. 2013).

\section{Tet proteins in neurogenesis}

Since the discovery of Tets and $5 \mathrm{hmC}$, their roles in mouse ESCs and development have been studied extensively. Both Tet 1 and Tet 2 are highly expressed in mouse ESCs, and transient knockdown of Tet 1 or Tet 2 results in promoter methylation or histone modification changes and down-regulates pluripotent genes, such as Nanog (Ito et al. 2010; Ficz et al. 2011; Williams et al. 2011; Xu et al. $2011 \mathrm{~b})$. In mouse ESCs, the depletion of Tet1 diminishes $5 \mathrm{hmC}$ levels at transcription start sites, whereas Tet2 depletion is primarily associated with gene body $5 \mathrm{hmC}$ depletion (Huang et al. 2014). Tet1 is noted to possess a dual role in both the activation and repression of its target genes, possibly depending on its binding cofactors or coordinating with other epigenetic modifiers (Fig. 3; Williams et al. 2011; Wu et al. 2011; Xu et al. 2011b). Among these, Ogt (O-linked $\mathrm{N}$-acetylglucosamine [OGlcNAc] transferase) (Chen et al. 2013; Deplus et al. 2013; Vella et al. 2013), Nanog (Costa et al. 2013), and PARP1 (poly [ADP-ribose] polymerase-1) (Doege et al. 2012) may be involved in TET-mediated gene activation. In contrast, SIN3A could be serving as a corepressor for TET-mediated gene silencing (Williams et al. 2011). Intriguingly, however, Tet1 knockout mice appear to be normal, viable, and fertile, suggesting their compatibility with embryonic and postnatal development (Dawlaty 


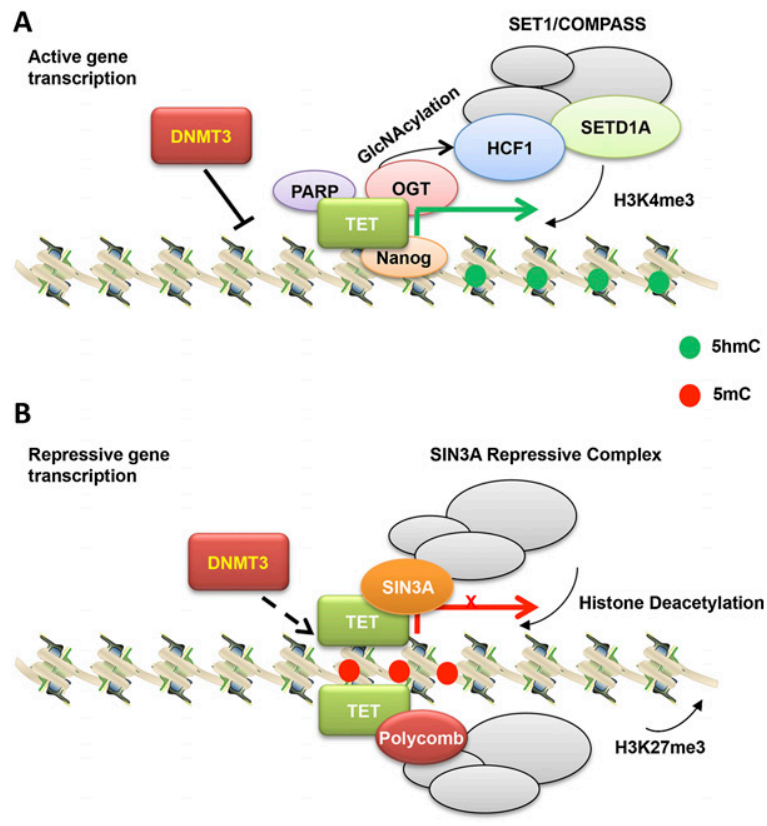

Figure 3. Dual roles of Tet proteins in activating and repressing gene expression. Tet proteins target and regulate specific gene expression by interacting with their coactivators or corepressors. (A) By directly interacting with Nanog, Tet proteins are recruited to Nanog target loci and regulate genes that are related to pluripotency and lineage commitment, possibly by altering the $5 \mathrm{hmC}$ status on those loci. Meanwhile, Tetl can recruit histone modifiers such as OGT, which can then recruit and GlcNAcylate HCF1 (host cell factor 1), a component of the H3K4 methyltransferase SET1/COMPASS complex, to generate an active chromatin state. Tet2 is known to recruit PARP1 to pluripotent loci, such as the Nanog promoter. Tet protein may also antagonize transcriptional repressors, such as DNMTs, to the active gene promoters. $(B)$ Tetl is found to colocalize with SIN3A and Polycomb-repressive complexes and possibly generate a repressive histone environment by $\mathrm{H} 3 \mathrm{~K} 27$ methylation and histone deacetylation.

et al. 2011; Yamaguchi et al. 2013). Tet1 and Tet2 doubleknockout mice are still viable despite reduced fertility, indicating the vital role of Tet3 in embryonic development (Dawlaty et al. 2013). Indeed, Tet3-deficient zygotes fail to convert $5 \mathrm{mC}$ to $5 \mathrm{hmC}$, impairing key epigenetic reprogramming genes, such as Oct4 or Nanog expression, and therefore affecting normal embryonic development (Gu et al. 2011).

Several recent studies have also begun to explore the roles of Tet proteins and their cofactors in neurogenesis. Zhang et al. (2013) showed that there is a $45 \%$ decrease of NSCs in the SGZ of Tet1 knockout mice compared with wild-type controls, and neurospheres isolated from Tet1 knockout mice demonstrate growth defects in vitro. Mechanistically, 39 genes are found to be both hypermethylated and down-regulated in NSCs isolated from the DG of adult Tet1 knockout mice. Many of those genes are involved in NSC proliferation, such as Galanin, Ng2, and Ngb (Zhang et al. 2013). Rudenko et al. (2013) found that Tet1 knockout mice exhibit impaired memory extinction and abnormally increased hippocampal longterm depression. Multiple neuronal activity-regulated genes, including Npas4, experience promoter hypermethylation and diminished expression (Rudenko et al. 2013). Kaas et al. (2013) overexpressed both the wild-type and catalytic dead forms of Tet1 in the mouse hippocampus. While only overexpression of the Tet 1 wild-type form globally altered the modified cytosine, surprisingly, both the Tet1 wild-type and catalytic dead forms changed the expression levels of a spectrum of genes that is involved in neuronal memory-associated genes and impairs contextual fear memory, indicating potential Tet functions independent of its enzymatic activity (Kaas et al. 2013). By manipulating a set of related genes in Xenopus, Xu et al. (2012) found that Tet3 works as a transcriptional regulator in early eye development and neurodevelopment. Morpholino antisense oligo depletion of Tet3 greatly inhibits master neuronal development genes, such as Pax6, Rx, and Six6 in the eye. Neuronal markers, such as Ngn2 and Tubb2b, as well as the neural crest markers Sox9 and Snail were also found to be repressed (Xu et al. 2012). These findings together indicate independent but interactive roles of Tet proteins in neurogenesis.

\section{Tet-interacting partners and $5 \mathrm{hm} C$ readers in neurogenesis}

Isocitrate dehydrogenases (IDHs) catalyze oxidative decarboxylation of isocitrate to produce $\alpha-\mathrm{KG}$, which is required for TET oxygenase activity (Xu et al. 2011a). It has been suggested that IDH deletions or mutations cause global $5 \mathrm{hmC}$ loss and are associated with lower-grade diffuse astrocytic glioma or glioblastoma (Parsons et al. 2008; Gorovets et al. 2012; Lian et al. 2012; Liang et al. 2013; Losman et al. 2013). Although the role of IDHs in neurogenesis remains to be studied, it is clear that IDHs, along with Tet proteins, are involved in the regulation of $5 \mathrm{hmC}$ production in the brain. Another enzyme, Ogt, was found to interact directly with Tet proteins (Deplus et al. 2013; Vella et al. 2013). Ogt relies on Tet proteins to bind to chromatin and GlcNAcylate host cell factor 1 (HCF1), a component of the H3K4 methyltransferase SET1/COMPASS complex, as well as trigger histone2B Ser112 GlcNAcylation (Fig. 3). Indeed, overexpression of Ogt increases the percentage of neurons exhibiting axon branching and the numbers of axonal filopodia (Francisco et al. 2009). Ogt is found to primarily reside in neuronal cell bodies and gradually declines during developmental stages and adulthood (Liu et al. 2012). These findings suggest a potential role for Ogt in neurogenesis. Given the role of Tet proteins and $5 \mathrm{hmC}$ in neurogenesis, more systematic identification of Tetinteracting proteins in the brain is definitely warranted.

Unlike MBPs, which have been extensively characterized, the identification and characterization of specific $5 \mathrm{hmC}$-binding proteins (5hmC readers) have only just begun. Recent studies suggest that many MBPs might have a dual capacity to interact with $5 \mathrm{hmC}$ as well. For example, MeCP2 binds to $5 \mathrm{hmC}$ in vitro. The MeCP2 
R113C mutation found in Rett syndrome patients abolishes its ability to bind to $5 \mathrm{hmC}$, implying a pathological role of $5 \mathrm{hmC}$ misinterpretation by its readers (Mellen et al. 2012). Although controversial, this observation suggests an interesting model in which MeCP2 could serve as a bridge to connect these cytosine variants and systematically control the transcription events. MeCP2 was originally thought to play a repressive role in transcription by binding and securing the hypermethylated promoters and recruiting repressive histone methyltransferase (Fuks et al. 2003). However, Zoghbi and colleagues (Chahrour et al. 2008) found that MeCP2 could possess dual regulatory roles in transcription by interacting with distinct cofactors. By specifically binding to the transcriptional activator CREB1 (cAMP response element-binding protein 1), MeCP2 could positively up-regulate certain genes, such as G-proteinregulated inducer of neurite outgrowth 1 (Gprn1) and opioid receptor $\kappa 1$ (Oprk1) (Chahrour et al. 2008). Consistently, recent work from the Jaenisch laboratory ( $\mathrm{Li}$ et al. 2013) showed global transcription repression in the absence of MeCP2 in human neurons. In their studies, genes with higher ratios of $5 \mathrm{hmC}$ to $5 \mathrm{mC}$ were more likely to be down-regulated in neurons. Thus, it is possible that by coordinating with $5 \mathrm{mC}$ or $5 \mathrm{hmC}$ in different genes, MeCP2 could positively or negatively regulate differential gene expression simultaneously to achieve neuronal plasticity. MBD3 can also colocalize with Tet 1 and $5 \mathrm{hmC}$ in ESCs, displaying a preference for 5 hmC over $5 \mathrm{mC}$ (Yildirim et al. 2011). Spruijt et al. (2013) applied large-scale quantitative mass spectrometry-based proteomics to identify cytosine variants' binding proteins in ESCs, NPCs, and the adult mouse brain. Many binding proteins identified display cell/tissue or modification specificity, at least in vitro. For example, Uhrf2, a E3 ubiquitin protein ligase, was found to specifically bind to $5 \mathrm{hmC}$, not $5 \mathrm{mC}$, in NPCs. Uhrf2 is up-regulated and highly expressed upon differentiation but is not expressed in mouse ESCs (Pichler et al. 2011). In mouse brains, Dlx1 exclusively interacts with $5 \mathrm{mC}$, while $\mathrm{Wdr} 76$ and Thy 28 are $5 \mathrm{hmC}$-specific readers. These data indicate a widespread network intertwined with partially overlapping readers of cytosine derivatives, and these readers can selectively bind to distinct derivatives within different cellular contexts to ensure proper functions. Some known positive and negative neurogenic regulators involved in cytosine modifications and their target genes are summarized in Figure 4. It will be important to identify specific readers in the context of neurogenesis to further our understanding of epigenetic regulation in neurogenesis.

Besides $5 \mathrm{hmC}$, $5 \mathrm{fC}$ and $5 \mathrm{caC}$ have also been identified in the Tet-mediated DNA demethylation pathway; however, due to the extremely low abundance of $5 \mathrm{fC}$ and $5 \mathrm{caC}$ in the genome, their functional roles have not been systematically explored (Ito et al. 2010, 2011; He et al. 2011). Genome-wide $5 \mathrm{fC} / 5 \mathrm{caC}$ profiling suggests that $5 \mathrm{fC}$ expression preferentially overlaps with poised enhancers over other distal regulatory elements. The loss of Tdg results in the accumulation of $5 \mathrm{fC}$ at those loci in ESCs (Shen et al. 2013; Song et al. 2013). Since the abundance of

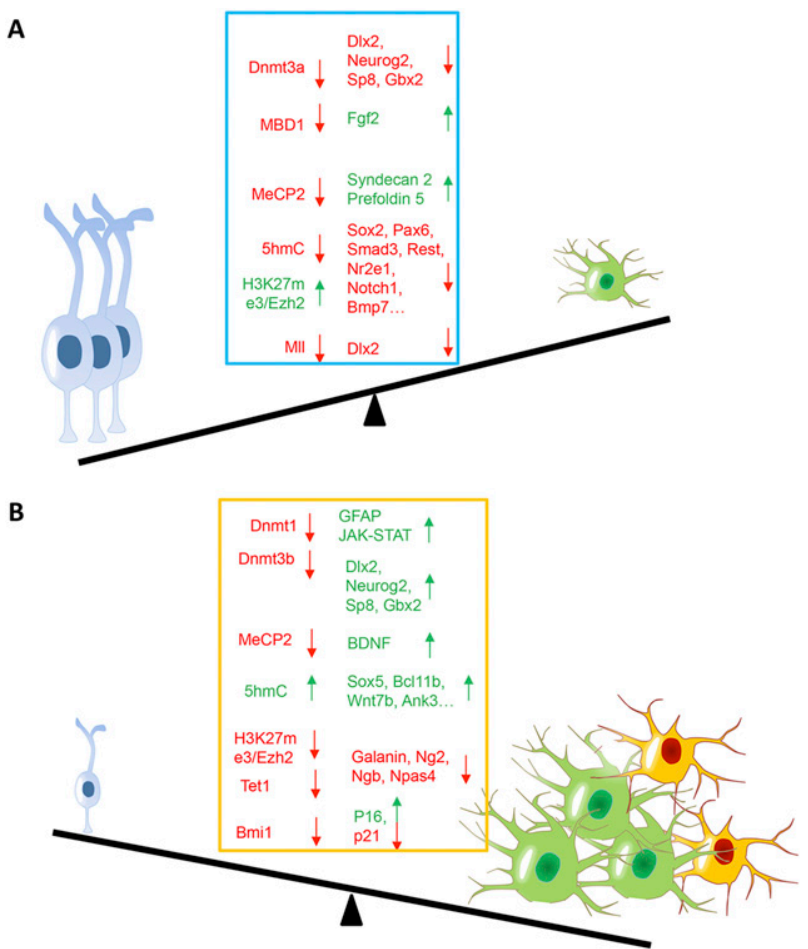

Figure 4. Positive and negative modulators in neurogenesis. Changes in transcriptional regulators and their downstream genes during neurogenesis are indicated in pairs. Red highlights the down-regulated factors or genes, and green highlights the upregulated factors or genes. (A) Alteration of the indicated factors impairs NSC differentiation and neurogenesis. $(B)$ Alteration of the indicated factors induces premature NSC differentiation and aberrant neurogenesis.

$5 \mathrm{fC} / 5 \mathrm{caC}$ is relatively higher in the brain than in other tissues, it would be interesting to explore their functions in neurogenesis using the tools that have been developed for these modifications (Song et al. 2012).

\section{Histone modifications}

One-hundred-forty-seven base pairs of DNA wrap around an octamer of histone proteins, which consists of two copies of histone variants (including $\mathrm{H} 2 \mathrm{~A}, \mathrm{H} 2 \mathrm{~B}, \mathrm{H} 3$, and $\mathrm{H} 4)$, to form a nucleosome. The $\mathrm{N}$-terminal tails of histone proteins are subjected to dynamic post-translational modifications, including methylation, acetylation, ubiquitination, phosphorylation, SUMOylation, ADP-ribosylation, and glycosylation (Bernstein et al. 2007; Kouzarides 2007; Ruthenburg et al. 2007; Margueron and Reinberg 2010). These histone codes provide binding docks for gene activators or repressors, which manipulate the chromatin structure and determine the accessibility of their underlying DNA sequence. Differently modified histones could have cross-talk with DNA modification factors to give rise to a complicated system for accurately regulating gene expression (Pattaroni and Jacob 2013). Both histone methylation and acetylation are known to play roles in regulating neurogenesis (Hsieh and Eisch 2010; 
Ma et al. 2010; Pereira et al. 2010; Sun et al. 2011b; Jobe et al. 2012).

\section{Histone methylation/demethylation in neurogenesis}

Dynamic histone methylation and demethylation of lysine or arginine residues are catalyzed by a spectrum of histone methyltransferases (HMTs) and histone demethylases (HDMs) and correlate with either an activated or a repressive transcriptional environment (Mosammaparast and Shi 2010; Black et al. 2012). The PcG and Trithorax (TrxG) complexes are antagonistic chromatin complexes that are organized into large multisubunits to bind to specific regions of DNA and direct the post-translational modification of histone (Ringrose and Paro 2007; Schuettengruber et al. 2007). Ezh2 from the PcG PRC2 (Polycomb-repressive complex 2) complex is responsible for generating repressive H3K27me3, which can be read by the PcG PRC1 complex (Schwartz and Pirrotta 2007). PcG-mediated repression can be dynamically counteracted by the TrxG group, which is responsible for generating active histone modifications such as $\mathrm{H} 3 \mathrm{~K} 4 \mathrm{me}$, which can be generated by a TrxG component, Mll1 (Schuettengruber et al. 2011). During neocortical development, PcG plays pivotal roles in the NSC neurogenic-to-astrogenic transition by epigenetically regulating expression of the specific neurogenic gene Neurogenin 1 (Ngn1). Depletion of PcG components, such as Ring1b or Ezh2, resulted in an extended neurogenic phase and delayed onset of astrogenesis (Hirabayashi et al. 2009). This notion was further supported by additional observation that deletion of Ezh2 largely removed H3K27me3 markers, derepressed a large panel of genes, and delicately altered the balance between self-renewal and differentiation as well as the timing of neurogenesis (Pereira et al. 2010). Another PcG PRC1 component, Bmil, is critical for neurogenesis in the SVZ. Depletion of Bmil results in the up-regulation of the cell cycle inhibitor p16 and causes a sharp depletion of NSCs both in vitro and in vivo. However, the proliferation of transient amplifying cells from the gut and forebrain as well as in vitro culture is largely unaffected in the absence of Bmil, indicating that differential epigenetic regulatory mechanisms function in distinct stages of neurogenesis (Molofsky et al. 2003). On the other hand, Bmil overexpression appears to promote the proliferation of adult SVZ NPCs and maintain their developmental potential (Fasano et al. 2007). Mll1 is expressed in the SVZ and OB and is required for the proliferation and neurogenesis of NSCs residing in these regions. NSCs from an Mll1deficient SVZ display severe impairment in neuronal differentiation. Dlx2, a homeodomain-containing transcription factor that regulates neuronal differentiation, is silenced in the absence of Mll1. At a molecular level, H3K4me3 is associated with the Dlx2 promoter in differentiated neurons; however, both H3K27me3 and H3K4me3 are found to be associated with the Dlx2 promoter when Mll1 is depleted, suggesting a key role for Mll1 in resolving bivalent modifications on the Dlx2 promoter and establishing an active transcriptional environment during differentiation (Lim et al.
2009|. G9a histone methyltransferase, which generates the repressive histone mark $\mathrm{H} 3 \mathrm{~K} 9 \mathrm{me} 3$, is expressed in the mouse retina through development. The loss of G9a in retina progenitor cells leads to a failure of terminal differentiation accompanied by several key genes being up-regulated and the loss of H3K9me3 (Katoh et al. 2012). Another H3K9me3 methyltransferase, SUV39H1, can be degraded by BDNF-mediated and nerve growth factor (NGF)-mediated signal cascades, which could promote the binding of the transcription factor CREB to DNA to enhance its regulated genes for neurite outgrowth (Sen and Snyder 2011).

Lysine-specific demethylase 1 (LSD1) was the first H3K4me3 lysine demethylase identified, leading to a completely novel view of histone dynamic regulation (Shi et al. 2004). Knockdown of LSD1 or inhibition of its activity leads to reduced NSC proliferation in the adult DG or in vitro culture (Sun et al. 2010). LSD1 can be recruited by the nuclear receptor TLX to its target genes for repression, and double knockdown of LSD1 and TLX rescues the proliferation arrest in NSCs (Sun et al. 2010). Jmjd3, another class of H3K27me3 demethylase, is required for neuronal differentiation. The silencing mediator for retinoid or thyroid hormone receptors (SMRT) binds to the promoter of the Jmjd3 gene in NSCs, and depletion of SMRT results in the derepression of Jmjd3. Up-regulation of Jmjd3 demethylates a number of neuronal genes, including Dcx, Nkx2.2, and Dlx5, causing neuronal differentiation (Fig. 4; Jepsen et al. 2007). In summary, proper histone methylation/demethylation is required to ensure that the correct set of genes is expressed in different neurogenic stages, and misregulation of this process often leads to severe neurological diseases (Nimura et al. 2010).

\section{Histone acetylation/deacetylation in neurogenesis}

Histone acetylation occurs at lysine residues and is catalyzed by histone acetyltransferases (HATs). Like histone methylation, histone acetylation is a reversible process triggered by histone deacetylases (HDACs) (Yang and Seto 2007). Both HATs and HDACs are known to be involved in neurogenesis. For example, the MYST family HAT Querkopf (Qkf, Myst4, and Morf) is highly expressed in the SVZ, and its deficiency in mice leads to cumulative defects in adult neurogenesis in vivo. Specifically, the number of OB interneurons is significantly reduced, accompanied by a lower number of migrating neuroblasts in the RMS (Merson et al. 2006). Querkopf is also involved in embryonic neurogenesis, since mice carrying a mutated Querkopf have defects in cerebral cortex development (Thomas and Voss 2004). CREB-binding protein (CBP), another HAT, is also critical in embryonic neural differentiation (Wang et al. 2010; Tsui et al. 2014).

In mammals, there are 18 HDACs with differential expression in various tissues. For instance, HDAC2 is upregulated during NSC differentiation into neurons, whereas HDACl is found primarily in glial cells in the adult brain (MacDonald and Roskams 2008). In a separate study, HDAC1 and HDAC2 were found to work redun- 
dantly to control neuronal development, and deletion of both forms causes severe hippocampal abnormalities (Montgomery et al. 2009). TLX, a transcription factor that is essential for NSC proliferation and self-renewal, recruits HDACs to its target genes, such as p21 and Pten, and plays a positive role in neuronal growth (Sun et al. 2007). Thus, different HDACs may play unique roles in different stages or different cell types during neurogenesis. However, the precise mechanism behind how the proper HDAC is chosen during this process requires further investigation.

Consistent with the fact that HDACs influence a variety of intrinsic pathways during neurogenesis, many pharmacological HDAC inhibitors are found to regulate neurogenesis. Trichostatin A (TSA), a well-known HDAC inhibitor, was found to reduce neurogenesis both in vivo and in vitro. In this process, TSA plays an opposite role at the transcriptional level by either promoting Bmp2 or inhibiting Smad7 at the same time (Shaked et al. 2008). These data support the notion that HDACs can simultaneously regulate genes that control different lineage specificities either positively or negatively to fulfill cellular commitment. In addition, valproic acid (VPA), another inhibitor of HDAC, was found to induce neuronal differentiation of adult hippocampal neural progenitors, whereas it inhibited astrocyte and oligodendrocyte differentiation. VPA treatment also induces the expression of NeuroD, a neurogenic transcription factor that promotes neuronal but suppresses glial differentiation (Hsieh et al. 2004). Our understanding of HDAC inhibitors, especially their precise roles on different HDACs in neurogenesis, is clearly still limited; however, the data above point to a viable solution for developing pharmacological treatments for patients suffering from neurological disorders related to abnormal neurogenesis.

\section{ncRNAs in neurogenesis}

Crick (1970) proposed the central dogma that the flow of genetic information within a biological system should be from DNA to RNA to protein. Now we know that only $2 \%$ of transcribed RNAs will eventually be translated into proteins, making the vast majority of transcripts "noncoding" (Consortium et al. 2012). However, except for the RNAs involved in translation, such as rRNA and tRNA, other ncRNAs, termed regulatory RNAs, can play a variety of roles in fine-tuning gene expression (Erdmann et al. 2001). Among these RNAs, miRNA (Filipowicz et al. 2008; Bartel 2009; Krol et al. 2010) and lncRNA (Batista and Chang 2013; Fatica and Bozzoni 2014) have been explored extensively in recent years.

\section{miRNAs in neurogenesis}

The first described miRNA, lin-4, can negatively regulate its target gene, LIN-14, during different developmental stages in Caenorhabditis elegans (Lee et al. 1993). The identification of the first miRNA conserved across species, let-7, opened the door for remarkable advances in the field of miRNA research dating from 2000 (Pasquinelli et al. 2000). miRNAs are usually derived from endogenous transcripts to first form primary miRNAs (pri-mRNAs), which can be processed by the RNase III endonuclease Drosha to become precursor miRNAs (pre-miRNAs). After being transported into cytoplasm, pre-miRNAs further associate with Dicer, another RNase III endonuclease, resulting in an $\sim 22$-base-pair (bp) mature miRNA duplex (Filipowicz et al. 2008; Jinek and Doudna 2009; Fabian et al. 2010; Huntzinger and Izaurralde 2011). One strand of mature miRNA integrates into RNA-induced silencing complex (RISC), which includes Argonaute (AGOs) and GW182 proteins, and silences its mRNA targets based on imperfect base pair matching (Rana 2007; Hutvagner and Simard 2008; Jinek and Doudna 2009; Ameres and Zamore 2013). The roles of specific miRNAs in neurogenesis have been reviewed extensively elsewhere (Liu and Zhao 2009; Li and Jin 2010; Shi et al. 2010; Kawahara et al. 2012; Lang and Shi 2012; Singh et al. 2014), so we only focus on the latest developments in miRNA biogenesis, function, and cross-talk with other epigenetic mechanisms for their potential impact on neurogenesis.

Since miRNAs play indispensable roles in neurogenesis, the disruption of the general miRNA biogenesis pathway could impact normal neurodevelopment. This notion is supported by the finding that Dicer deletion in a subset of RGs around mouse E14 results in overproduction of cortical neurons. Interestingly, many of the abnormal neurons are actually produced postnatally, indicating a role for Dicer in the transition of active embryonic RGs to the quiescent adult form (Nowakowski et al. 2013). In addition, both Drosha and AGO2 may also regulate neurogenesis (Pepper et al. 2009; Knuckles et al. 2012; Ouchi et al. 2013). Moreover, other miRNA biogenesis regulators are found to be involved in the modulation of neurogenesis. For example, Lin28 controls the biogenesis of the let-7 family by inhibiting their maturation during the precursor stage (Heo et al. 2008). Recent data suggest that Sox 2 can bind to the promoter of Lin 28 and positively regulate its expression by inducing histone acetylation. Lin28 then participates in directing neurogenesis by manipulating let-7 levels. Furthermore, overexpression of let-7 can reduce NPC proliferation and inhibit neuronal differentiation (Cimadamore et al. 2013). Taken together, these data emphasize the importance of a functional miRNA pathway to proper neurogenesis.

Specific miRNAs have been shown to regulate neurogenesis. miR-124 was shown to regulate NSC differentiation in the SVZ by targeting the SRY-box transcription factor Sox9. Overexpression of miR-124 could promote neuronal differentiation, whereas knockdown of miR-124 could maintain NSC precursor identity (Cheng et al. 2009). In particular, the miRNA-mediated feedback regulatory loop mechanism could play important roles in controlling neural cell fate and neurogenesis. It has been shown that let-7d can inhibit NSC proliferation and promote NSC differentiation by modulating the previously established TLX-miR-9 negative regulatory loop (Zhao et al. 2009, 2013). Let-7d can directly bind to TLX mRNA and inhibit TLX expression post-transcriptionally, adding another layer to the delicate balance between NSC proliferation and differentiation. 
Cross-talk between miRNA and other epigenetic regulators in regulating neurogenesis has been actively explored in recent years. Using a proteomics approach, Crabtree and colleagues (Lessard et al. 2007) initially identified a subunit switch of the SWI/SNF chromatin remodeling complex during neurodevelopment. During neurodevelopment, the protein levels of BAF45a and BAF53a, two components in the SWI/SNF complex, decline dramatically and are substituted by their homologs, BAF45b/c and BAF53b (Lessard et al. 2007). A subsequent study from the same group revealed that $\mathrm{miR}-9^{\star}$ and $\mathrm{miR}-124$, two abundant miRNAs in the brain, are responsible for repressing BAF53a in this transition (Yoo et al. 2009). The brain-enriched miR137 also serves as a good example, with two lines of evidence. First, miR-137 expression is epigenetically controlled by MeCP2 and Sox2, and its overexpression and depletion correlate with NSC proliferation and differentiation, respectively. miR-137 targets the H3K27me3 methyltransferase Ezh2, which can lead to the modulation of neurogenesis-related genes (Szulwach et al. 2010). Second, miR-137 forms a regulatory loop with TLX and LSD1. LSD1 is a direct target of miR-137, and overexpression of miR-137 in mouse embryonic brains leads to premature differentiation accompanied by reduced LSD1 levels. Meanwhile, miR-137 is negatively regulated by transcription factor TLX, showing another example of TLX-mediated neurogenesis (Sun et al. 2011a). The cross-talk among different epigenetic mechanisms ensures the precise control of neurogenesis and proper neuronal functions.

\section{$\operatorname{lncRNAs}$ in neurogenesis}

lncRNAs are usually $>200 \mathrm{bp}$ in length, distinguishing them from most short regulatory RNAs, such as miRNAs; lncRNAs regulate gene expression on the transcriptional level in cis or in trans by interacting with epigenetic modifiers (Fatica and Bozzoni 2014).

The roles of lncRNAs in neurogenesis have just begun to be appreciated. For instance, metastasis-associated lung adenocarcinoma transcript 1 (Malat1) is highly expressed in neurons, and a loss-of-function study in the hippocampus revealed the misregulation of synapse functional genes in the absence of Malat1 (Bernard et al. 2010). Another example is the coactivator lncRNA Dlx6 opposite strand transcript 1 (Dlx6os1 or Evf2), an antisense RNA in proximity to Dlx6 and Dlx5 (Feng et al. 2006). Dlx6os 1 controls the expression of its adjacent Dlx5 and Dlx6 by recruiting transcription activator Dlx2 and MeCP2. Dlx6os1 mutations show reduced interneurons in the early postnatal hippocampus and DG (Feng et al. 2006; Bond et al. 2009). More recently, Lin et al. (2014) identified one lncRNA, TUNA (Tcll upstream neuronassociated lincRNA), that displays CNS-specific expression and appears to play key roles in neurogenesis and the neuronal functions in zebrafish. Furthermore, TUNA expression is specifically silenced in the striatum in HD patients, implying the possibility of lncRNA in the etiology of neurological and neurodevelopmental disorders (Lin et al. 2014). With the development of high-throughput RNA sequencing methods, more lncRNAs should be identified, and their comprehensive functions in neurogenesis should be unraveled.

\section{Emerging roles of RNA modifications}

In addition to DNA and histone modifications, $>100$ posttranscriptionally modified ribonucleosides have been identified in various types of RNA (Jia et al. 2013). Furthermore, recent studies also suggest that post-transcriptional RNA modifications could be dynamic and might have functions beyond fine-tuning the structure and function of RNA. These dynamic RNA modifications represent another realm for gene regulation in the form of "RNA epigenetics," which is just beginning to be explored (Jia et al. 2011).

An example of a functional RNA modification is $N^{6}$ methyladenosine $\left(\mathrm{m}^{6} \mathrm{~A}\right) \cdot \mathrm{m}^{6} \mathrm{~A}$ is a conserved internal modification found in almost all eukaryotic nuclear RNAs as well as in some viral RNAs, such as Rous sarcoma virus, that replicates inside host nuclei (Beemon and Keith 1977; Carroll et al. 1990). The discoveries of functionally important methylases and demethylases, together with the recently revealed $\mathrm{m}^{6} \mathrm{~A}$ distributions in mammalian transcriptomes, are strong indicators of regulatory functions for this dynamic modification (Jia et al. 2013; Niu et al. 2013). Furthermore, a $\mathrm{m}^{6} \mathrm{~A}$-specific reader, YTH domain family 2 (YTHDF2), has been identified and is responsible for the translocation of bound mRNA from translation pools to P bodies for RNA decay (Wang et al. 2014a). It was shown that the methylation of mRNA related to a developmental regulator could antagonize $\mathrm{HuR}$ (an RNAbinding protein that recognizes AU-rich elements on the 3' untranslated region or mRNA) and facilitate miRNAmediated gene silencing. The depletion of $\mathrm{m}^{6} \mathrm{~A}$ allowed the association of HuR and stabilized these transcripts in mouse ESCs (Fig. 5; Wang et al. 2014b).

The role of $\mathrm{m}^{6} \mathrm{~A}$ in neurogenesis remains to be defined; however, the expression of genes involved in $\mathrm{m}^{6} \mathrm{~A}$ methylation and demethylation could be differentially regulated during neuronal differentiation, suggesting a potential role for this RNA modification in neurogenesis (P Jin, unpubl.).

\section{Conclusions}

Neurogenesis is a complex process that is under extensive regulation. Epigenetic mechanisms (including DNA modification, histone modification, and noncoding regulatory RNAs) form vast networks to precisely regulate intrinsic factors (including transcription factors, signaling molecules, and neuronal genes) to maintain NSC proliferation and multipotency and direct cell lineage commitment and terminal neural differentiation in response to extracellular and environmental cues. Many examples discussed in this review suggest that epigenetic mechanisms are involved in all aspects of neurogenesis and that there is extensive cross-talk among distinct epigenetic mechanisms. The development of new technologies, such as high-throughput sequencing and genomic editing, will soon enable significant progress in untangling the details of these epigenetic regulatory mechanisms, especially their internetworking, during neurogenesis. 
A
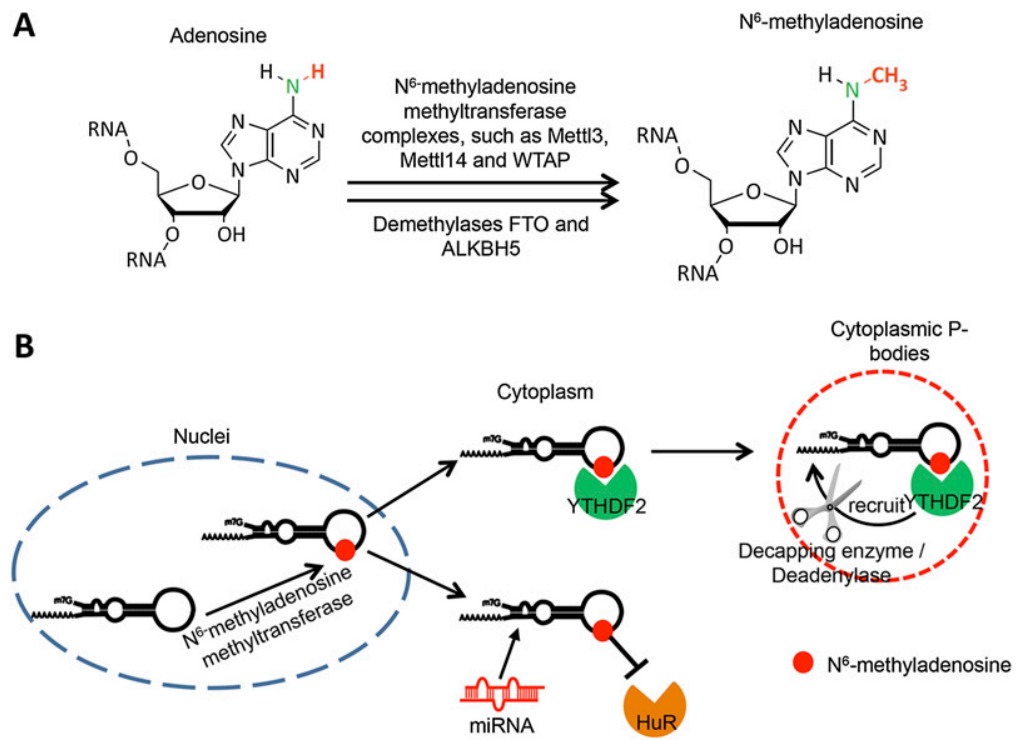

Figure 5. RNA methylation $\left(\mathrm{m}^{6} \mathrm{~A}\right)$ and its potential biological functions. (A) Dynamic RNA methylation and its methyltransferases/demethylases are indicated. (B) RNA methylation occurs in nuclei and is then transported to the cytoplasm, where $\mathrm{m}^{6} \mathrm{~A}$ can be bound by the $\mathrm{m}^{6} \mathrm{~A}$ reader YTHDF2, an RNA-binding protein. YTHDF2 facilitates the transportation of modified RNA into $\mathrm{P}$ bodies and there recruits RNA metabolic enzymes for RNA degradation. RNA methylation could also antagonize the binding of AU-rich element-binding protein HuR and allow miRNA to regulate mRNA half-life.

\section{Acknowledgments}

We apologize to the researchers whose work is not cited due to space limitations. We thank Cheryl Strauss and Brittany Phillips for critical reading of this manuscript, and Yuanxiang Zhu for graphic illustrations. Work in the laboratory of P.J. was supported by the National Institutes of Health (NS051630, NS079625, MH102690, and HD073162), Simons Foundation, March of Dimes, and NARSAD. B.Y. is supported by a post-doctoral fellowship from the National Ataxia Foundation.

\section{References}

Alvarez-Buylla A, Garcia-Verdugo JM, Tramontin AD. 2001. A unified hypothesis on the lineage of neural stem cells. Nat Rev Neurosci 2: 287-293.

Ameres SL, Zamore PD. 2013. Diversifying microRNA sequence and function. Nat Rev Mol Cell Biol 14: 475-488.

Amir RE, Van den Veyver IB, Wan M, Tran CQ, Francke U, Zoghbi HY. 1999. Rett syndrome is caused by mutations in X-linked MECP2, encoding methyl-CpG-binding protein 2. Nat Genet 23: 185-188.

Arita K, Ariyoshi M, Tochio H, Nakamura Y, Shirakawa M. 2008. Recognition of hemi-methylated DNA by the SRA protein UHRF1 by a base-flipping mechanism. Nature 455: 818-821.

Avvakumov GV, Walker JR, Xue S, Li Y, Duan S, Bronner C, Arrowsmith $\mathrm{CH}$, Dhe-Paganon S. 2008. Structural basis for recognition of hemi-methylated DNA by the SRA domain of human UHRF1. Nature 455: 822-825.

Balmer NV, Weng MK, Zimmer B, Ivanova VN, Chambers SM, Nikolaeva E, Jagtap S, Sachinidis A, Hescheler J, Waldmann T, et al. 2012. Epigenetic changes and disturbed neural development in a human embryonic stem cell-based model relating to the fetal valproate syndrome. Hum Mol Genet 21: 4104-4114.

Barkho BZ, Song H, Aimone JB, Smrt RD, Kuwabara T, Nakashima $\mathrm{K}$, Gage FH, Zhao X. 2006. Identification of astrocyte-expressed factors that modulate neural stem/progenitor cell differentiation. Stem Cells Dev 15: 407-421.

Barreto G, Schafer A, Marhold J, Stach D, Swaminathan SK, Handa V, Doderlein G, Maltry N, Wu W, Lyko F, et al. 2007. Gadd45a promotes epigenetic gene activation by repairmediated DNA demethylation. Nature 445: 671-675.

Bartel DP. 2009. MicroRNAs: target recognition and regulatory functions. Cell 136: 215-233.
Batista PJ, Chang HY. 2013. Long noncoding RNAs: cellular address codes in development and disease. Cell 152: 1298-1307.

Bedard A, Cossette M, Levesque M, Parent A. 2002. Proliferating cells can differentiate into neurons in the striatum of normal adult monkey. Neurosci Lett 328: 213-216.

Beemon K, Keith J. 1977. Localization of N6-methyladenosine in the Rous sarcoma virus genome. J Mol Biol 113: 165-179.

Bernard D, Prasanth KV, Tripathi V, Colasse S, Nakamura T, Xuan Z, Zhang MQ, Sedel F, Jourdren L, Coulpier F, et al. 2010. A long nuclear-retained non-coding RNA regulates synaptogenesis by modulating gene expression. EMBO J 29: 3082-3093.

Bernstein E, Allis CD. 2005. RNA meets chromatin. Genes Dev 19: $1635-1655$.

Bernstein BE, Meissner A, Lander ES. 2007. The mammalian epigenome. Cell 128: 669-681.

Bestor TH. 2000. The DNA methyltransferases of mammals. Hum Mol Genet 9: 2395-2402.

Bird AP. 1986. CpG-rich islands and the function of DNA methylation. Nature 321: 209-213.

Black JC, Van Rechem C, Whetstine JR. 2012. Histone lysine methylation dynamics: establishment, regulation, and biological impact. Mol Cell 48: 491-507.

Bogdanovic O, Veenstra GJ. 2009. DNA methylation and methyl-CpG binding proteins: developmental requirements and function. Chromosoma 118: 549-565.

Bond AM, Vangompel MJ, Sametsky EA, Clark MF, Savage JC, Disterhoft JF, Kohtz JD. 2009. Balanced gene regulation by an embryonic brain ncRNA is critical for adult hippocampal GABA circuitry. Nat Neurosci 12: 1020-1027.

Cameron HA, McKay RD. 2001. Adult neurogenesis produces a large pool of new granule cells in the dentate gyrus. J Comp Neurol 435: 406-417.

Campbell K, Gotz M. 2002. Radial glia: multi-purpose cells for vertebrate brain development. Trends Neurosci 25: 235-238.

Cao L, Jiao X, Zuzga DS, Liu Y, Fong DM, Young D, During MJ. 2004. VEGF links hippocampal activity with neurogenesis, learning and memory. Nat Genet 36: 827-835.

Carroll SM, Narayan P, Rottman FM. 1990. N6-methyladenosine residues in an intron-specific region of prolactin premRNA. Mol Cell Biol 10: 4456-4465.

Cedar H, Bergman Y. 2009. Linking DNA methylation and histone modification: patterns and paradigms. Nat Rev Genet 10: 295-304. 
Chahrour M, Jung SY, Shaw C, Zhou X, Wong ST, Qin J, Zoghbi HY. 2008. MeCP2, a key contributor to neurological disease, activates and represses transcription. Science 320: 12241229.

Chen WG, Chang Q, Lin Y, Meissner A, West AE, Griffith EC, Jaenisch R, Greenberg ME. 2003. Derepression of BDNF transcription involves calcium-dependent phosphorylation of MeCP2. Science 302: 885-889.

Chen Q, Chen Y, Bian C, Fujiki R, Yu X. 2013. TET2 promotes histone O-GlcNAcylation during gene transcription. Nature 493: $561-564$.

Cheng MF. 2013. Hypothalamic neurogenesis in the adult brain. Front Neuroendocrinol 34: 167-178.

Cheng LC, Pastrana E, Tavazoie M, Doetsch F. 2009. miR-124 regulates adult neurogenesis in the subventricular zone stem cell niche. Nat Neurosci 12: 399-408.

Cimadamore F, Amador-Arjona A, Chen C, Huang CT, Terskikh AV. 2013. SOX2-LIN28/let-7 pathway regulates proliferation and neurogenesis in neural precursors. Proc Natl Acad Sci 110: E3017-E3026.

Cohen S, Gabel HW, Hemberg M, Hutchinson AN, Sadacca LA, Ebert DH, Harmin DA, Greenberg RS, Verdine VK, Zhou Z, et al. 2011. Genome-wide activity-dependent MeCP2 phosphorylation regulates nervous system development and function. Neuron 72: 72-85.

Colak D, Mori T, Brill MS, Pfeifer A, Falk S, Deng C, Monteiro R, Mummery C, Sommer L, Gotz M. 2008. Adult neurogenesis requires Smad4-mediated bone morphogenic protein signaling in stem cells. J Neurosci 28: 434-446.

Consortium EP, Bernstein BE, Birney E, Dunham I, Green ED, Gunter C, Snyder M. 2012. An integrated encyclopedia of DNA elements in the human genome. Nature 489: 57-74.

Costa Y, Ding J, Theunissen TW, Faiola F, Hore TA, Shliaha PV, Fidalgo M, Saunders A, Lawrence M, Dietmann S, et al. 2013. NANOG-dependent function of TET1 and TET2 in establishment of pluripotency. Nature 495: 370-374.

Crick F. 1970. Central dogma of molecular biology. Nature 227: 561-563.

Dawlaty MM, Ganz K, Powell BE, Hu YC, Markoulaki S, Cheng AW, Gao Q, Kim J, Choi SW, Page DC, et al. 2011. Tet1 is dispensable for maintaining pluripotency and its loss is compatible with embryonic and postnatal development. Cell Stem Cell 9: 166-175.

Dawlaty MM, Breiling A, Le T, Raddatz G, Barrasa MI, Cheng AW, Gao Q, Powell BE, Li Z, Xu M, et al. 2013. Combined deficiency of Tet 1 and Tet 2 causes epigenetic abnormalities but is compatible with postnatal development. Dev Cell 24: 310-323.

Deplus R, Delatte B, Schwinn MK, Defrance M, Mendez J, Murphy N, Dawson MA, Volkmar M, Putmans P, Calonne E, et al. 2013. TET2 and TET3 regulate GlcNAcylation and H3K4 methylation through OGT and SET1/COMPASS. EMBO J 32: 645-655.

Doege CA, Inoue K, Yamashita T, Rhee DB, Travis S, Fujita R, Guarnieri P, Bhagat G, Vanti WB, Shih A, et al. 2012. Earlystage epigenetic modification during somatic cell reprogramming by Parp1 and Tet2. Nature 488: 652-655.

Drapeau E, Montaron MF, Aguerre S, Abrous DN. 2007. Learning-induced survival of new neurons depends on the cognitive status of aged rats. J Neurosci 27: 6037-6044.

Erdmann VA, Barciszewska MZ, Hochberg A, de Groot N, Barciszewski J. 2001. Regulatory RNAs. Cell Mol Life Sci 58: $960-977$.

Ernst A, Alkass K, Bernard S, Salehpour M, Perl S, Tisdale J, Possnert G, Druid H, Frisen J. 2014. Neurogenesis in the striatum of the adult human brain. Cell 156: 1072-1083.
Fabian MR, Sonenberg N, Filipowicz W. 2010. Regulation of mRNA translation and stability by microRNAs. Annu Rev Biochem 79: 351-379.

Fan G, Martinowich K, Chin MH, He F, Fouse SD, Hutnick L, Hattori D, Ge W, Shen Y, Wu H, et al. 2005. DNA methylation controls the timing of astrogliogenesis through regulation of JAK-STAT signaling. Development 132: 3345-3356.

Fasano CA, Dimos JT, Ivanova NB, Lowry N, Lemischka IR, Temple S. 2007. shRNA knockdown of Bmi-1 reveals a critical role for p21-Rb pathway in NSC self-renewal during development. Cell Stem Cell 1: 87-99.

Fatica A, Bozzoni I. 2014. Long non-coding RNAs: new players in cell differentiation and development. Nat Rev Genet 15: 7-21.

Felsenfeld G. 2014. A brief history of epigenetics. Cold Spring Harb Perspect Biol 6: a018200.

Feng J, Chang H, Li E, Fan G. 2005. Dynamic expression of de novo DNA methyltransferases Dnmt3a and Dnmt3b in the central nervous system. J Neurosci Res 79: 734-746.

Feng J, Bi C, Clark BS, Mady R, Shah P, Kohtz JD. 2006. The Evf2 noncoding RNA is transcribed from the Dlx-5/6 ultraconserved region and functions as a Dlx-2 transcriptional coactivator. Genes Dev 20: 1470-1484.

Feng J, Zhou Y, Campbell SL, Le T, Li E, Sweatt JD, Silva AJ, Fan G. 2010. Dnmt1 and Dnmt3a maintain DNA methylation and regulate synaptic function in adult forebrain neurons. Nat Neurosci 13: 423-430.

Ficz G, Branco MR, Seisenberger S, Santos F, Krueger F, Hore TA, Marques CJ, Andrews S, Reik W. 2011. Dynamic regulation of 5-hydroxymethylcytosine in mouse ES cells and during differentiation. Nature 473: 398-402.

Filipowicz W, Bhattacharyya SN, Sonenberg N. 2008. Mechanisms of post-transcriptional regulation by microRNAs: are the answers in sight? Nat Rev Genet 9: 102-114.

Filippov V, Kronenberg G, Pivneva T, Reuter K, Steiner B, Wang LP, Yamaguchi M, Kettenmann H, Kempermann G. 2003. Subpopulation of nestin-expressing progenitor cells in the adult murine hippocampus shows electrophysiological and morphological characteristics of astrocytes. Mol Cell Neurosci 23: 373-382.

Francisco H, Kollins K, Varghis N, Vocadlo D, Vosseller K, Gallo G. 2009. O-GLcNAc post-translational modifications regulate the entry of neurons into an axon branching program. Dev Neurobiol 69: 162-173.

Fuks F, Hurd PJ, Wolf D, Nan X, Bird AP, Kouzarides T. 2003. The methyl-CpG-binding protein MeCP2 links DNA methylation to histone methylation. J Biol Chem 278: 4035-4040.

Fukuda S, Kato F, Tozuka Y, Yamaguchi M, Miyamoto Y, Hisatsune T. 2003. Two distinct subpopulations of nestinpositive cells in adult mouse dentate gyrus. I Neurosci 23: 9357-9366.

Gage FH. 2000. Mammalian neural stem cells. Science 287: $1433-1438$.

Gage FH, Temple S. 2013. Neural stem cells: generating and regenerating the brain. Neuron 80: 588-601.

Ge S, Goh EL, Sailor KA, Kitabatake Y, Ming GL, Song H. 2006. GABA regulates synaptic integration of newly generated neurons in the adult brain. Nature 439: 589-593.

Ge S, Sailor KA, Ming GL, Song H. 2008. Synaptic integration and plasticity of new neurons in the adult hippocampus. I Physiol 586: 3759-3765.

Goldberg AD, Allis CD, Bernstein E. 2007. Epigenetics: a landscape takes shape. Cell 128: 635-638.

Goll MG, Bestor TH. 2005. Eukaryotic cytosine methyltransferases. Annu Rev Biochem 74: 481-514.

Golshani P, Hutnick L, Schweizer F, Fan G. 2005. Conditional Dnmtl deletion in dorsal forebrain disrupts development of 
somatosensory barrel cortex and thalamocortical long-term potentiation. Thalamus Relat Syst 3: 227-233.

Gorovets D, Kannan K, Shen R, Kastenhuber ER, Islamdoust N, Campos C, Pentsova E, Heguy A, Jhanwar SC, Mellinghoff IK et al. 2012. IDH mutation and neuroglial developmental features define clinically distinct subclasses of lower grade diffuse astrocytic glioma. Clin Cancer Res 18: 2490-2501.

Goto K, Numata M, Komura JI, Ono T, Bestor TH, Kondo H. 1994. Expression of DNA methyltransferase gene in mature and immature neurons as well as proliferating cells in mice. Differentiation 56: 39-44.

Gotz M, Huttner WB. 2005. The cell biology of neurogenesis. Nat Rev Mol Cell Biol 6: 777-788.

Gu TP, Guo F, Yang H, Wu HP, Xu GF, Liu W, Xie ZG, Shi L, He $X$, Jin SG, et al. 2011. The role of Tet3 DNA dioxygenase in epigenetic reprogramming by oocytes. Nature 477: 606-610.

Guo JU, Su Y, Zhong C, Ming GL, Song H. 2011. Hydroxylation of 5-methylcytosine by TET1 promotes active DNA demethylation in the adult brain. Cell 145: 423-434.

Gupta A, Tsai LH, Wynshaw-Boris A. 2002. Life is a journey: a genetic look at neocortical development. Nat Rev Genet 3: 342-355.

Hack MA, Saghatelyan A, de Chevigny A, Pfeifer A, AsheryPadan R, Lledo PM, Gotz M. 2005. Neuronal fate determinants of adult olfactory bulb neurogenesis. Nat Neurosci 8: 865-872.

Hahn MA, Qiu R, Wu X, Li AX, Zhang H, Wang J, Jui J, Jin SG, Jiang Y, Pfeifer GP, et al. 2013. Dynamics of 5-hydroxymethylcytosine and chromatin marks in mammalian neurogenesis. Cell Reports 3: 291-300.

Hartfuss E, Galli R, Heins N, Gotz M. 2001. Characterization of CNS precursor subtypes and radial glia. Dev Biol 229: 15-30.

Hashimoto H, Horton JR, Zhang X, Bostick M, Jacobsen SE, Cheng X. 2008. The SRA domain of UHRF1 flips 5-methylcytosine out of the DNA helix. Nature 455: 826-829.

Haubensak W, Attardo A, Denk W, Huttner WB. 2004. Neurons arise in the basal neuroepithelium of the early mammalian telencephalon: a major site of neurogenesis. Proc Natl Acad Sci 101: 3196-3201.

He YF, Li BZ, Li Z, Liu P, Wang Y, Tang Q, Ding J, Jia Y, Chen Z, $\mathrm{Li}$ L, et al. 2011. Tet-mediated formation of 5-carboxylcytosine and its excision by TDG in mammalian DNA. Science 333: 1303-1307.

Hemberger M, Dean W, Reik W. 2009. Epigenetic dynamics of stem cells and cell lineage commitment: digging Waddington's canal. Nat Rev Mol Cell Biol 10: 526-537.

Hendrich B, Bird A. 1998. Identification and characterization of a family of mammalian methyl-CpG binding proteins. Mol Cell Biol 18: 6538-6547.

Heo I, Joo C, Cho J, Ha M, Han J, Kim VN. 2008. Lin28 mediates the terminal uridylation of let-7 precursor MicroRNA. Mol Cell 32: 276-284.

Hirabayashi Y, Suzki N, Tsuboi M, Endo TA, Toyoda T, Shinga J, Koseki H, Vidal M, Gotoh Y. 2009. Polycomb limits the neurogenic competence of neural precursor cells to promote astrogenic fate transition. Neuron 63: 600-613.

Holliday R, Pugh JE. 1975. DNA modification mechanisms and gene activity during development. Science 187: 226-232.

Hotchkiss RD. 1948. The quantitative separation of purines, pyrimidines, and nucleosides by paper chromatography. I Biol Chem 175: 315-332.

Hsieh J, Eisch AJ. 2010. Epigenetics, hippocampal neurogenesis, and neuropsychiatric disorders: unraveling the genome to understand the mind. Neurobiol Dis 39: 73-84.

Hsieh J, Nakashima K, Kuwabara T, Mejia E, Gage FH. 2004. Histone deacetylase inhibition-mediated neuronal differen- tiation of multipotent adult neural progenitor cells. Proc Natl Acad Sci 101: 16659-16664.

Huang Y, Chavez L, Chang X, Wang X, Pastor WA, Kang J, Zepeda-Martinez JA, Pape UJ, Jacobsen SE, Peters B, et al. 2014. Distinct roles of the methylcytosine oxidases Tet1 and Tet2 in mouse embryonic stem cells. Proc Natl Acad Sci 111: 1361-1366.

Huntzinger E, Izaurralde E. 2011. Gene silencing by microRNAs: contributions of translational repression and mRNA decay. Nat Rev Genet 12: 99-110.

Huttner WB, Brand M. 1997. Asymmetric division and polarity of neuroepithelial cells. Curr Opin Neurobiol 7: 29-39.

Hutvagner G, Simard MJ. 2008. Argonaute proteins: key players in RNA silencing. Nat Rev Mol Cell Biol 9: 22-32.

Imayoshi I, Sakamoto M, Yamaguchi M, Mori K, Kageyama R. 2010. Essential roles of Notch signaling in maintenance of neural stem cells in developing and adult brains. I Neurosci 30: $3489-3498$.

Imayoshi I, Shimojo H, Sakamoto M, Ohtsuka T, Kageyama R. 2013. Genetic visualization of notch signaling in mammalian neurogenesis. Cell Mol Life Sci 70: 2045-2057.

Ito S, D'Alessio AC, Taranova OV, Hong K, Sowers LC, Zhang Y. 2010. Role of Tet proteins in $5 \mathrm{mC}$ to $5 \mathrm{hmC}$ conversion, EScell self-renewal and inner cell mass specification. Nature 466: 1129-1133.

Ito S, Shen L, Dai Q, Wu SC, Collins LB, Swenberg JA, He C, Zhang Y. 2011. Tet proteins can convert 5-methylcytosine to 5-formylcytosine and 5-carboxylcytosine. Science 333: 13001303.

Iyer LM, Tahiliani M, Rao A, Aravind L. 2009. Prediction of novel families of enzymes involved in oxidative and other complex modifications of bases in nucleic acids. Cell Cycle 8: $1698-1710$.

Jaenisch R, Bird A. 2003. Epigenetic regulation of gene expression: how the genome integrates intrinsic and environmental signals. Nat Genet (Suppl) 33: 245-254.

Jepsen K, Solum D, Zhou T, McEvilly RJ, Kim HJ, Glass CK, Hermanson O, Rosenfeld MG. 2007. SMRT-mediated repression of an $\mathrm{H} 3 \mathrm{~K} 27$ demethylase in progression from neural stem cell to neuron. Nature 450: 415-419.

Jia G, Fu Y, Zhao X, Dai Q, Zheng G, Yang Y, Yi C, Lindahl T, Pan T, Yang YG, et al. 2011. $N^{6}$-methyladenosine in nuclear RNA is a major substrate of the obesity-associated FTO. Nat Chem Biol 7: 885-887.

Jia G, Fu Y, He C. 2013. Reversible RNA adenosine methylation in biological regulation. Trends Genet 29: 108-115.

Jin K, Zhu Y, Sun Y, Mao XO, Xie L, Greenberg DA. 2002. Vascular endothelial growth factor (VEGF) stimulates neurogenesis in vitro and in vivo. Proc Natl Acad Sci 99: 1194611950.

Jinek M, Doudna JA. 2009. A three-dimensional view of the molecular machinery of RNA interference. Nature 457: 405412.

Jobe EM, McQuate AL, Zhao X. 2012. Crosstalk among epigenetic pathways regulates neurogenesis. Front Neurosci 6: 59.

Jones PA, Baylin SB. 2002. The fundamental role of epigenetic events in cancer. Nat Rev Genet 3: 415-428.

Kaas GA, Zhong C, Eason DE, Ross DL, Vachhani RV, Ming GL, King JR, Song H, Sweatt JD. 2013. TET1 controls CNS 5methylcytosine hydroxylation, active DNA demethylation, gene transcription, and memory formation. Neuron 79: 1086-1093.

Katoh K, Yamazaki R, Onishi A, Sanuki R, Furukawa T. 2012. G9a histone methyltransferase activity in retinal progenitors is essential for proper differentiation and survival of mouse retinal cells. J Neurosci 32: 17658-17670. 
Kawahara H, Imai T, Okano H. 2012. MicroRNAs in neural stem cells and neurogenesis. Front Neurosci 6: 30.

Kempermann G, Kuhn HG, Gage FH. 1997. More hippocampal neurons in adult mice living in an enriched environment. Nature 386: 493-495.

Knuckles P, Vogt MA, Lugert S, Milo M, Chong MM, Hautbergue GM, Wilson SA, Littman DR, Taylor V. 2012. Drosha regulates neurogenesis by controlling neurogenin 2 expression independent of microRNAs. Nat Neurosci 15: 962-969.

Kokoeva MV, Yin H, Flier JS. 2005. Neurogenesis in the hypothalamus of adult mice: potential role in energy balance. Science 310: 679-683.

Kouzarides T. 2007. Chromatin modifications and their function. Cell 128: 693-705.

Kriaucionis S, Heintz N. 2009. The nuclear DNA base 5hydroxymethylcytosine is present in Purkinje neurons and the brain. Science 324: 929-930.

Kriegstein A, Alvarez-Buylla A. 2009. The glial nature of embryonic and adult neural stem cells. Annu Rev Neurosci 32: $149-184$.

Krol J, Loedige I, Filipowicz W. 2010. The widespread regulation of microRNA biogenesis, function and decay. Nat Rev Genet 11: 597-610.

Lang MF, Shi Y. 2012. Dynamic roles of microRNAs in neurogenesis. Front Neurosci 6: 71 .

Lee RC, Feinbaum RL, Ambros V. 1993. The C. elegans heterochronic gene lin-4 encodes small RNAs with antisense complementarity to lin-14. Cell 75: 843-854.

Lee DA, Bedont JL, Pak T, Wang H, Song J, Miranda-Angulo A, Takiar V, Charubhumi V, Balordi F, Takebayashi $\mathrm{H}$, et al. 2012. Tanycytes of the hypothalamic median eminence form a diet-responsive neurogenic niche. Nat Neurosci 15: 700702.

Lessard J, Wu JI, Ranish JA, Wan M, Winslow MM, Staahl BT, $\mathrm{Wu} \mathrm{H}$, Aebersold R, Graef IA, Crabtree GR. 2007. An essential switch in subunit composition of a chromatin remodeling complex during neural development. Neuron 55: 201-215.

Lewis JD, Meehan RR, Henzel WJ, Maurer-Fogy I, Jeppesen P, Klein F, Bird A. 1992. Purification, sequence, and cellular localization of a novel chromosomal protein that binds to methylated DNA. Cell 69: 905-914.

Li X, Jin P. 2010. Roles of small regulatory RNAs in determining neuronal identity. Nat Rev Neurosci 11: 329-338.

Li L, Xie T. 2005. Stem cell niche: structure and function. Annu Rev Cell Dev Biol 21: 605-631.

Li E, Bestor TH, Jaenisch R. 1992. Targeted mutation of the DNA methyltransferase gene results in embryonic lethality. Cell 69: 915-926.

Li X, Barkho BZ, Luo Y, Smrt RD, Santistevan NJ, Liu C, Kuwabara T, Gage FH, Zhao X. 2008. Epigenetic regulation of the stem cell mitogen Fgf- 2 by Mbd1 in adult neural stem/ progenitor cells. J Biol Chem 283: 27644-27652.

Li Y, Wang H, Muffat J, Cheng AW, Orlando DA, Loven J, Kwok SM, Feldman DA, Bateup HS, Gao Q, et al. 2013. Global transcriptional and translational repression in human-embryonic-stem-cell-derived Rett syndrome neurons. Cell Stem Cell 13: 446-458.

Lian CG, Xu Y, Ceol C, Wu F, Larson A, Dresser K, Xu W, Tan L, Hu Y, Zhan Q, et al. 2012. Loss of 5-hydroxymethylcytosine is an epigenetic hallmark of melanoma. Cell 150: 1135-1146.

Liang G, Zhang Y. 2013. Embryonic stem cell and induced pluripotent stem cell: an epigenetic perspective. Cell Res 23: 49-69.

Liang DC, Liu HC, Yang CP, Jaing TH, Hung IJ, Yeh TC, Chen SH, Hou JY, Huang YJ, Shih YS, et al. 2013. Cooperating gene mutations in childhood acute myeloid leukemia with special reference on mutations of ASXL1, TET2, IDH1, IDH2, and DNMT3A. Blood 121: 2988-2995.

Lie DC, Colamarino SA, Song HJ, Desire L, Mira H, Consiglio A, Lein ES, Jessberger S, Lansford H, Dearie AR, et al. 2005. Wnt signalling regulates adult hippocampal neurogenesis. Nature 437: 1370-1375.

Lim DA, Tramontin AD, Trevejo JM, Herrera DG, GarciaVerdugo JM, Alvarez-Buylla A. 2000. Noggin antagonizes BMP signaling to create a niche for adult neurogenesis. Neuron 28: 713-726.

Lim DA, Huang YC, Swigut T, Mirick AL, Garcia-Verdugo JM, Wysocka I, Ernst P, Alvarez-Buylla A. 2009. Chromatin remodelling factor Mll1 is essential for neurogenesis from postnatal neural stem cells. Nature 458: 529-533.

Lin N, Chang KY, Li Z, Gates K, Rana ZA, Dang J, Zhang D, Han T, Yang CS, Cunningham TJ, et al. 2014. An evolutionarily conserved long noncoding RNA TUNA controls pluripotency and neural lineage commitment. Mol Cell 53: 1005-1019.

Liu C, Zhao X. 2009. MicroRNAs in adult and embryonic neurogenesis. Neuromolecular Med 11: 141-152.

Liu Y, Li X, Yu Y, Shi J, Liang Z, Run X, Li Y, Dai CL, GrundkeIqbal I, Iqbal K, et al. 2012. Developmental regulation of protein O-GlcNAcylation, O-GlcNAc transferase, and OGlcNAcase in mammalian brain. PLOS ONE 7: e43724.

Lledo PM, Alonso M, Grubb MS. 2006. Adult neurogenesis and functional plasticity in neuronal circuits. Nat Rev Neurosci 7: 179-193.

Long JE, Swan C, Liang WS, Cobos I, Potter GB, Rubenstein JL. 2009. Dlx1\&2 and Mash1 transcription factors control striatal patterning and differentiation through parallel and overlapping pathways. J Comp Neurol 512: 556-572.

Losman JA, Looper RE, Koivunen P, Lee S, Schneider RK, McMahon C, Cowley GS, Root DE, Ebert BL, Kaelin WG Jr. 2013. (R)-2-hydroxyglutarate is sufficient to promote leukemogenesis and its effects are reversible. Science 339: 1621-1625.

Ma DK, Jang $\mathrm{MH}$, Guo JU, Kitabatake Y, Chang ML, PowAnpongkul N, Flavell RA, Lu B, Ming GL, Song H. 2009. Neuronal activity-induced Gadd45b promotes epigenetic DNA demethylation and adult neurogenesis. Science 323: 1074-1077.

Ma DK, Marchetto MC, Guo JU, Ming GL, Gage FH, Song H. 2010. Epigenetic choreographers of neurogenesis in the adult mammalian brain. Nat Neurosci 13: 1338-1344.

MacDonald JL, Roskams AJ. 2008. Histone deacetylases 1 and 2 are expressed at distinct stages of neuro-glial development. Dev Dyn 237: 2256-2267.

Machold R, Hayashi S, Rutlin M, Muzumdar MD, Nery S, Corbin JG, Gritli-Linde A, Dellovade T, Porter JA, Rubin LL, et al. 2003. Sonic hedgehog is required for progenitor cell maintenance in telencephalic stem cell niches. Neuron 39: 937-950.

Magavi SS, Leavitt BR, Macklis JD. 2000. Induction of neurogenesis in the neocortex of adult mice. Nature 405: 951-955.

Maier E, Nord H, von Hofsten J, Gunhaga L. 2011. A balance of BMP and notch activity regulates neurogenesis and olfactory nerve formation. PLOS ONE 6: e17379.

Margueron R, Reinberg D. 2010. Chromatin structure and the inheritance of epigenetic information. Nat Rev Genet 11: 285-296.

Markakis EA, Palmer TD, Randolph-Moore L, Rakic P, Gage FH. 2004. Novel neuronal phenotypes from neural progenitor cells. J Neurosci 24: 2886-2897.

Martinowich K, Hattori D, Wu H, Fouse S, He F, Hu Y, Fan G, Sun YE. 2003. DNA methylation-related chromatin remod- 
eling in activity-dependent BDNF gene regulation. Science 302: $890-893$.

Martins-Taylor K, Schroeder DI, LaSalle JM, Lalande M, Xu RH. 2012. Role of DNMT3B in the regulation of early neural and neural crest specifiers. Epigenetics 7: 71-82.

Mateus-Pinheiro A, Pinto L, Sousa N. 2011. Epigenetic (de)regulation of adult hippocampal neurogenesis: implications for depression. Clini Epigenetics 3: 5.

Mellen M, Ayata P, Dewell S, Kriaucionis S, Heintz N. 2012. $\mathrm{MeCP} 2$ binds to $5 \mathrm{hmC}$ enriched within active genes and accessible chromatin in the nervous system. Cell 151: 14171430.

Merkle FT, Tramontin AD, Garcia-Verdugo JM, Alvarez-Buylla A. 2004. Radial glia give rise to adult neural stem cells in the subventricular zone. Proc Natl Acad Sci 101: 17528-17532.

Merkle FT, Mirzadeh Z, Alvarez-Buylla A. 2007. Mosaic organization of neural stem cells in the adult brain. Science 317: 381-384.

Merson TD, Dixon MP, Collin C, Rietze RL, Bartlett PF, Thomas T, Voss AK. 2006. The transcriptional coactivator Querkopf controls adult neurogenesis. J Neurosci 26: 1135911370.

Miller FD, Gauthier AS. 2007. Timing is everything: making neurons versus glia in the developing cortex. Neuron 54: 357-369.

Miller CA, Sweatt JD. 2007. Covalent modification of DNA regulates memory formation. Neuron 53: 857-869.

Ming GL, Song H. 2005. Adult neurogenesis in the mammalian central nervous system. Annu Rev Neurosci 28: 223-250.

Ming GL, Song H. 2011. Adult neurogenesis in the mammalian brain: significant answers and significant questions. Neuron 70: 687-702.

Molofsky AV, Pardal R, Iwashita T, Park IK, Clarke MF, Morrison SJ. 2003. Bmi-1 dependence distinguishes neural stem cell self-renewal from progenitor proliferation. Nature 425: 962-967.

Montgomery RL, Hsieh J, Barbosa AC, Richardson JA, Olson EN. 2009. Histone deacetylases 1 and 2 control the progression of neural precursors to neurons during brain development. Proc Natl Acad Sci 106: 7876-7881.

Mori T, Buffo A, Gotz M. 2005. The novel roles of glial cells revisited: the contribution of radial glia and astrocytes to neurogenesis. Curr Top Dev Biol 69: 67-99.

Mosammaparast N, Shi Y. 2010. Reversal of histone methylation: biochemical and molecular mechanisms of histone demethylases. Annu Rev Biochem 79: 155-179.

Mouret A, Gheusi G, Gabellec MM, de Chaumont F, OlivoMarin JC, Lledo PM. 2008. Learning and survival of newly generated neurons: when time matters. I Neurosci 28: 11511-11516.

Munzel M, Globisch D, Bruckl T, Wagner M, Welzmiller V, Michalakis S, Muller M, Biel M, Carell T. 2010. Quantification of the sixth DNA base hydroxymethylcytosine in the brain. Angew Chem 49: 5375-5377.

Murray PS, Holmes PV. 2011. An overview of brain-derived neurotrophic factor and implications for excitotoxic vulnerability in the hippocampus. Int J Pept 2011: 654085.

Nguyen S, Meletis K, Fu D, Jhaveri S, Jaenisch R. 2007. Ablation of de novo DNA methyltransferase Dnmt3a in the nervous system leads to neuromuscular defects and shortened lifespan. Dev Dyn 236: 1663-1676.

Nimura K, Ura K, Kaneda Y. 2010. Histone methyltransferases: regulation of transcription and contribution to human disease. J Mol Med 88: 1213-1220.

Niu Y, Zhao X, Wu YS, Li MM, Wang XJ, Yang YG. 2013. N6methyl-adenosine $\left(\mathrm{m}^{6} \mathrm{~A}\right)$ in RNA: an old modification with a novel epigenetic function. Genomics Proteomics Bioinformatics 11: 8-17.

Noctor SC, Flint AC, Weissman TA, Dammerman RS, Kriegstein AR. 2001. Neurons derived from radial glial cells establish radial units in neocortex. Nature 409: 714-720.

Noctor SC, Martinez-Cerdeno V, Ivic L, Kriegstein AR. 2004. Cortical neurons arise in symmetric and asymmetric division zones and migrate through specific phases. Nat Neurosci 7: 136-144.

Nowakowski TJ, Mysiak KS, O'Leary T, Fotaki V, Pratt T, Price DJ. 2013. Loss of functional Dicer in mouse radial glia cellautonomously prolongs cortical neurogenesis. Dev Biol 382: 530-537.

Okano H, Temple S. 2009. Cell types to order: temporal specification of CNS stem cells. Curr Opin Neurobiol 19: 112-119.

Okano M, Bell DW, Haber DA, Li E. 1999. DNA methyltransferases Dnmt3a and Dnmt3b are essential for de novo methylation and mammalian development. Cell 99: 247257.

Ouchi Y, Banno Y, Shimizu Y, Ando S, Hasegawa H, Adachi K, Iwamoto T. 2013. Reduced adult hippocampal neurogenesis and working memory deficits in the Dgcr8-deficient mouse model of 22q11.2 deletion-associated schizophrenia can be rescued by IGF2. I Neurosci 33: 9408-9419.

Parsons DW, Jones S, Zhang X, Lin JC, Leary RJ, Angenendt P, Mankoo P, Carter H, Siu IM, Gallia GL, et al. 2008. An integrated genomic analysis of human glioblastoma multiforme. Science 321: 1807-1812.

Pasquinelli AE, Reinhart BJ, Slack F, Martindale MQ, Kuroda MI, Maller B, Hayward DC, Ball EE, Degnan B, Muller P, et al. 2000. Conservation of the sequence and temporal expression of let-7 heterochronic regulatory RNA. Nature 408: 86-89.

Pastor WA, Pape UJ, Huang Y, Henderson HR, Lister R, Ko M, McLoughlin EM, Brudno Y, Mahapatra S, Kapranov P, et al. 2011. Genome-wide mapping of 5-hydroxymethylcytosine in embryonic stem cells. Nature 473: 394-397.

Pastor WA, Aravind L, Rao A. 2013. TETonic shift: biological roles of TET proteins in DNA demethylation and transcription. Nat Rev Mol Cell Biol 14: 341-356.

Pattaroni C, Jacob C. 2013. Histone methylation in the nervous system: functions and dysfunctions. Mol Neurobiol 47: 740756.

Penn NW, Suwalski R, O’Riley C, Bojanowski K, Yura R. 1972. The presence of 5-hydroxymethylcytosine in animal deoxyribonucleic acid. Biochem J 126: 781-790.

Pepper AS, Beerman RW, Bhogal B, Jongens TA. 2009. Argonaute2 suppresses Drosophila fragile X expression preventing neurogenesis and oogenesis defects. PLOS ONE 4: e7618.

Pereira JD, Sansom SN, Smith J, Dobenecker MW, Tarakhovsky A, Livesey FJ. 2010. Ezh2, the histone methyltransferase of PRC2, regulates the balance between self-renewal and differentiation in the cerebral cortex. Proc Natl Acad Sci 107: 15957-15962.

Pfaffeneder T, Hackner B, Truss M, Munzel M, Muller M, Deiml CA, Hagemeier C, Carell T. 2011. The discovery of 5formylcytosine in embryonic stem cell DNA. Angew Chem 50: 7008-7012.

Pichler G, Wolf P, Schmidt CS, Meilinger D, Schneider K, Frauer C, Fellinger K, Rottach A, Leonhardt H. 2011. Cooperative DNA and histone binding by Uhrf2 links the two major repressive epigenetic pathways. I Cell Biochem 112: 25852593.

Platel JC, Gordon V, Heintz T, Bordey A. 2009. GFAP-GFP neural progenitors are antigenically homogeneous and anchored in their enclosed mosaic niche. Glia 57: 66-78. 
Platel JC, Dave KA, Gordon V, Lacar B, Rubio ME, Bordey A. 2010. NMDA receptors activated by subventricular zone astrocytic glutamate are critical for neuroblast survival prior to entering a synaptic network. Neuron 65: 859-872.

Probst AV, Dunleavy E, Almouzni G. 2009. Epigenetic inheritance during the cell cycle. Nat Rev Mol Cell Biol 10: 192206.

Pruunsild P, Sepp M, Orav E, Koppel I, Timmusk T. 2011 Identification of cis-elements and transcription factors regulating neuronal activity-dependent transcription of human BDNF gene. I Neurosci 31: 3295-3308.

Rai K, Huggins IJ, James SR, Karpf AR, Jones DA, Cairns BR. 2008. DNA demethylation in zebrafish involves the coupling of a deaminase, a glycosylase, and gadd45. Cell 135: 12011212.

Ramocki MB, Peters SU, Tavyev YJ, Zhang F, Carvalho CM, Schaaf CP, Richman R, Fang P, Glaze DG, Lupski JR, et al. 2009. Autism and other neuropsychiatric symptoms are prevalent in individuals with MeCP2 duplication syndrome. Ann Neurol 66: 771-782.

Rana TM. 2007. Illuminating the silence: understanding the structure and function of small RNAs. Nat Rev Mol Cell Biol 8: 23-36.

Rhee KD, Yu J, Zhao CY, Fan G, Yang XJ. 2012. Dnmt1dependent DNA methylation is essential for photoreceptor terminal differentiation and retinal neuron survival. Cell Death Dis 3: e427.

Ringrose L, Paro R. 2007. Polycomb/Trithorax response elements and epigenetic memory of cell identity. Development 134: 223-232.

Rudenko A, Dawlaty MM, Seo J, Cheng AW, Meng J, Le T, Faull KF, Jaenisch R, Tsai LH. 2013. Tet1 is critical for neuronal activity-regulated gene expression and memory extinction. Neuron 79: 1109-1122.

Ruthenburg AJ, Li H, Patel DJ, Allis CD. 2007. Multivalent engagement of chromatin modifications by linked binding modules. Nat Rev Mol Cell Biol 8: 983-994.

Schuettengruber B, Chourrout D, Vervoort $M$, Leblanc B, Cavalli G. 2007. Genome regulation by polycomb and trithorax proteins. Cell 128: 735-745.

Schuettengruber B, Martinez AM, Iovino N, Cavalli G. 2011. Trithorax group proteins: switching genes on and keeping them active. Nat Rev Mol Cell Biol 12: 799-814.

Schwartz YB, Pirrotta V. 2007. Polycomb silencing mechanisms and the management of genomic programmes. Nat Rev Genet 8: 9-22.

Sen N, Snyder SH. 2011. Neurotrophin-mediated degradation of histone methyltransferase by S-nitrosylation cascade regulates neuronal differentiation. Proc Natl Acad Sci 108: 20178-20183.

Seri B, Garcia-Verdugo JM, Collado-Morente L, McEwen BS, Alvarez-Buylla A. 2004. Cell types, lineage, and architecture of the germinal zone in the adult dentate gyrus. I Comp Neurol 478: 359-378.

Shahbazian MD, Antalffy B, Armstrong DL, Zoghbi HY. 2002. Insight into Rett syndrome: MeCP2 levels display tissue- and cell-specific differences and correlate with neuronal maturation. Hum Mol Genet 11: 115-124.

Shaked M, Weissmuller K, Svoboda H, Hortschansky P, Nishino N, Wolfl S, Tucker KL. 2008. Histone deacetylases control neurogenesis in embryonic brain by inhibition of BMP2/4 signaling. PLOS ONE 3: e2668.

Sheikh MA, Malik YS, Yu H, Lai M, Wang X, Zhu X. 2013. Epigenetic regulation of Dpp6 expression by Dnmt3b and its novel role in the inhibition of RA induced neuronal differentiation of P19 cells. PLOS ONE 8: e55826.
Shen L, Wu H, Diep D, Yamaguchi S, D'Alessio AC, Fung HL, Zhang K, Zhang Y. 2013. Genome-wide analysis reveals TETand TDG-dependent 5-methylcytosine oxidation dynamics. Cell 153: 692-706.

Shi Y, Lan F, Matson C, Mulligan P, Whetstine JR, Cole PA, Casero RA, Shi Y. 2004. Histone demethylation mediated by the nuclear amine oxidase homolog LSD1. Cell 119: 941-953.

Shi Y, Zhao X, Hsieh J, Wichterle H, Impey S, Banerjee S, Neveu P, Kosik KS. 2010. MicroRNA regulation of neural stem cells and neurogenesis. J Neurosci 30: 14931-14936.

Singh T, Jauhari A, Pandey A, Singh P, Pant AB, Parmar D, Yadav S. 2014. Regulatory triangle of neurodegeneration, adult neurogenesis and microRNAs. CNS Neurol Disord Drug Targets 13: 96-103.

Smith ZD, Meissner A. 2013. DNA methylation: roles in mammalian development. Nat Rev Genet 14: 204-220.

Smrt RD, Eaves-Egenes J, Barkho BZ, Santistevan NJ, Zhao C, Aimone JB, Gage FH, Zhao X. 2007. Mecp2 deficiency leads to delayed maturation and altered gene expression in hippocampal neurons. Neurobiol Dis 27: 77-89.

Song CX, Szulwach KE, Fu Y, Dai Q, Yi C, Li X, Li Y, Chen CH, Zhang W, Jian X, et al. 2011. Selective chemical labeling reveals the genome-wide distribution of 5-hydroxymethylcytosine. Nat Biotechnol 29: 68-72.

Song CX, Yi C, He C. 2012. Mapping recently identified nucleotide variants in the genome and transcriptome. Nat Biotechnol 30: 1107-1116.

Song CX, Szulwach KE, Dai Q, Fu Y, Mao SQ, Lin L, Street C, Li Y, Poidevin M, Wu H, et al. 2013. Genome-wide profiling of 5 -formylcytosine reveals its roles in epigenetic priming. Cell 153: 678-691.

Sousa-Ferreira L, Almeida LP, Cavadas C. 2014. Role of hypothalamic neurogenesis in feeding regulation. Trends Endocrinol Metab 25: 80-88.

Spruijt CG, Gnerlich F, Smits AH, Pfaffeneder T, Jansen PW, Bauer C, Munzel M, Wagner M, Muller M, Khan F, et al. 2013. Dynamic readers for 5-(hydroxy)methylcytosine and its oxidized derivatives. Cell 152: 1146-1159.

Stadtfeld M, Hochedlinger K. 2010. Induced pluripotency: history, mechanisms, and applications. Genes Dev 24: 22392263.

Suh H, Consiglio A, Ray J, Sawai T, D'Amour KA, Gage FH. 2007. In vivo fate analysis reveals the multipotent and selfrenewal capacities of $\mathrm{Sox}^{+}$neural stem cells in the adult hippocampus. Cell Stem Cell 1: 515-528.

Sun G, Yu RT, Evans RM, Shi Y. 2007. Orphan nuclear receptor TLX recruits histone deacetylases to repress transcription and regulate neural stem cell proliferation. Proc Natl Acad Sci 104: 15282-15287.

Sun G, Alzayady K, Stewart R, Ye P, Yang S, Li W, Shi Y. 2010. Histone demethylase LSD1 regulates neural stem cell proliferation. Mol Cell Biol 30: 1997-2005.

Sun G, Ye P, Murai K, Lang MF, Li S, Zhang H, Li W, Fu C, Yin J, Wang A, et al. 2011a. miR-137 forms a regulatory loop with nuclear receptor TLX and LSD1 in neural stem cells. Nat Commun 2: 529.

Sun J, Sun J, Ming GL, Song H. 2011b. Epigenetic regulation of neurogenesis in the adult mammalian brain. Eur I Neurosci 33: $1087-1093$

Suzuki MM, Bird A. 2008. DNA methylation landscapes: provocative insights from epigenomics. Nat Rev Genet 9: 465476.

Szulwach KE, Li X, Smrt RD, Li Y, Luo Y, Lin L, Santistevan NJ, Li W, Zhao X, Jin P. 2010. Cross talk between microRNA and epigenetic regulation in adult neurogenesis. I Cell Biol 189: 127-141. 
Szulwach KE, Li X, Li Y, Song CX, Han JW, Kim S, Namburi S, Hermetz K, Kim JJ, Rudd MK, et al. 2011a. Integrating 5-hydroxymethylcytosine into the epigenomic landscape of human embryonic stem cells. PLoS Genet 7: e1002154.

Szulwach KE, Li X, Li Y, Song CX, Wu H, Dai Q, Irier H, Upadhyay AK, Gearing M, Levey AI, et al. 2011b. 5-hmCmediated epigenetic dynamics during postnatal neurodevelopment and aging. Nat Neurosci 14: 1607-1616.

Tahiliani M, Koh KP, Shen Y, Pastor WA, Bandukwala H, Brudno Y, Agarwal S, Iyer LM, Liu DR, Aravind L, et al. 2009. Conversion of 5-methylcytosine to 5-hydroxymethylcytosine in mammalian DNA by MLL partner TET1. Science 324: 930-935.

Takahashi K, Yamanaka S. 2006. Induction of pluripotent stem cells from mouse embryonic and adult fibroblast cultures by defined factors. Cell 126: 663-676.

Tashiro A, Sandler VM, Toni N, Zhao C, Gage FH. 2006. NMDA-receptor-mediated, cell-specific integration of new neurons in adult dentate gyrus. Nature 442: 929-933.

Thomas T, Voss AK. 2004. Querkopf, a histone acetyltransferase, is essential for embryonic neurogenesis. Front Biosci 9: 24-31.

Tsui D, Voronova A, Gallagher D, Kaplan DR, Miller FD, Wang J. 2014. CBP regulates the differentiation of interneurons from ventral forebrain neural precursors during murine development. Dev Biol 385: 230-241.

van Praag H, Schinder AF, Christie BR, Toni N, Palmer TD, Gage FH. 2002. Functional neurogenesis in the adult hippocampus. Nature 415: 1030-1034.

Vella P, Scelfo A, Jammula S, Chiacchiera F, Williams K, Cuomo A, Roberto A, Christensen J, Bonaldi T, Helin K, et al. 2013. Tet proteins connect the O-linked $\mathrm{N}$-acetylglucosamine transferase Ogt to chromatin in embryonic stem cells. Mol Cell 49: 645-656.

Waclaw RR, Allen ZJ 2nd, Bell SM, Erdelyi F, Szabo G, Potter SS, Campbell K. 2006. The zinc finger transcription factor Sp8 regulates the generation and diversity of olfactory bulb interneurons. Neuron 49: 503-516.

Waddington CH. 1939. An introduction to modern genetics. G. Allen and Unwin, London.

Wang J, Weaver IC, Gauthier-Fisher A, Wang H, He L, Yeomans J, Wondisford F, Kaplan DR, Miller FD. 2010. CBP histone acetyltransferase activity regulates embryonic neural differentiation in the normal and Rubinstein-Taybi syndrome brain. Dev Cell 18: 114-125.

Wang X, Lu Z, Gomez A, Hon GC, Yue Y, Han D, Fu Y, Parisien M, Dai Q, Jia G, et al. 2014a. N6-methyladenosine-dependent regulation of messenger RNA stability. Nature 505: 117-120.

Wang Y, Li Y, Toth JI, Petroski MD, Zhang Z, Zhao JC. 2014b. N6-methyladenosine modification destabilizes developmental regulators in embryonic stem cells. Nat Cell Biol 16: 191198.

Williams K, Christensen J, Pedersen MT, Johansen JV, Cloos PA, Rappsilber J, Helin K. 2011. TET1 and hydroxymethylcytosine in transcription and DNA methylation fidelity. Nature 473: 343-348.

Wu H, Coskun V, Tao J, Xie W, Ge W, Yoshikawa K, Li E, Zhang Y, Sun YE. 2010. Dnmt3a-dependent nonpromoter DNA methylation facilitates transcription of neurogenic genes. Science 329: 444-448.

Wu H, D'Alessio AC, Ito S, Xia K, Wang Z, Cui K, Zhao K, Sun YE, Zhang Y. 2011. Dual functions of Tet1 in transcriptional regulation in mouse embryonic stem cells. Nature 473: 389393.

Wu Z, Huang K, Yu J, Le T, Namihira M, Liu Y, Zhang J, Xue Z, Cheng L, Fan G. 2012. Dnmt3a regulates both proliferation and differentiation of mouse neural stem cells. I Neurosci Res 90: 1883-1891.

Xu W, Yang H, Liu Y, Yang Y, Wang P, Kim SH, Ito S, Yang C, Wang P, Xiao MT, et al. 2011a. Oncometabolite 2-hydroxyglutarate is a competitive inhibitor of $\alpha$-ketoglutarate-dependent dioxygenases. Cancer Cell 19: 17-30.

Xu Y, Wu F, Tan L, Kong L, Xiong L, Deng J, Barbera AJ, Zheng L, Zhang H, Huang S, et al. 2011b. Genome-wide regulation of $5 \mathrm{hmC}, 5 \mathrm{mC}$, and gene expression by Tet1 hydroxylase in mouse embryonic stem cells. Mol Cell 42: 451-464.

Xu Y, Xu C, Kato A, Tempel W, Abreu JG, Bian C, Hu Y, Hu D, Zhao B, Cerovina T, et al. 2012. Tet3 CXXC domain and dioxygenase activity cooperatively regulate key genes for Xenopus eye and neural development. Cell 151: 1200-1213.

Yamaguchi S, Shen L, Liu Y, Sendler D, Zhang Y. 2013. Role of Tet1 in erasure of genomic imprinting. Nature 504: 460-464.

Yang XJ, Seto E. 2007. HATs and HDACs: from structure, function and regulation to novel strategies for therapy and prevention. Oncogene 26: 5310-5318.

Yildirim O, Li R, Hung JH, Chen PB, Dong X, Ee LS, Weng Z, Rando OJ, Fazzio TG. 2011. Mbd3/NURD complex regulates expression of 5-hydroxymethylcytosine marked genes in embryonic stem cells. Cell 147: 1498-1510.

Yoo AS, Staahl BT, Chen L, Crabtree GR. 2009. MicroRNAmediated switching of chromatin-remodelling complexes in neural development. Nature 460: 642-646.

Yu M, Hon GC, Szulwach KE, Song CX, Zhang L, Kim A, Li X, Dai Q, Shen Y, Park B, et al. 2012. Base-resolution analysis of 5 -hydroxymethylcytosine in the mammalian genome. Cell 149: $1368-1380$.

Zhang L, Lu X, Lu J, Liang H, Dai Q, Xu GL, Luo C, Jiang H, He C. 2012. Thymine DNA glycosylase specifically recognizes 5-carboxylcytosine-modified DNA. Nat Chem Biol 8: 328 330.

Zhang RR, Cui QY, Murai K, Lim YC, Smith ZD, Jin S, Ye P, Rosa L, Lee YK, Wu HP, et al. 2013. Tet1 regulates adult hippocampal neurogenesis and cognition. Cell Stem Cell 13: 237-245.

Zhao X, Ueba T, Christie BR, Barkho B, McConnell MJ, Nakashima K, Lein ES, Eadie BD, Willhoite AR, Muotri $\mathrm{AR}$, et al. 2003. Mice lacking methyl-CpG binding protein 1 have deficits in adult neurogenesis and hippocampal function. Proc Natl Acad Sci 100: 6777-6782.

Zhao C, Deng W, Gage FH. 2008. Mechanisms and functional implications of adult neurogenesis. Cell 132: 645-660.

Zhao C, Sun G, Li S, Shi Y. 2009. A feedback regulatory loop involving microRNA-9 and nuclear receptor TLX in neural stem cell fate determination. Nat Struct Mol Biol 16: 365371.

Zhao C, Sun G, Ye P, Li S, Shi Y. 2013. MicroRNA let-7d regulates the TLX/microRNA-9 cascade to control neural cell fate and neurogenesis. Scientific reports 3: 1329.

Zhou Z, Hong EJ, Cohen S, Zhao WN, Ho HY, Schmidt L, Chen WG, Lin Y, Savner E, Griffith EC, et al. 2006. Brain-specific phosphorylation of $\mathrm{MeCP} 2$ regulates activity-dependent Bdnf transcription, dendritic growth, and spine maturation. Neuron 52: 255-269. 


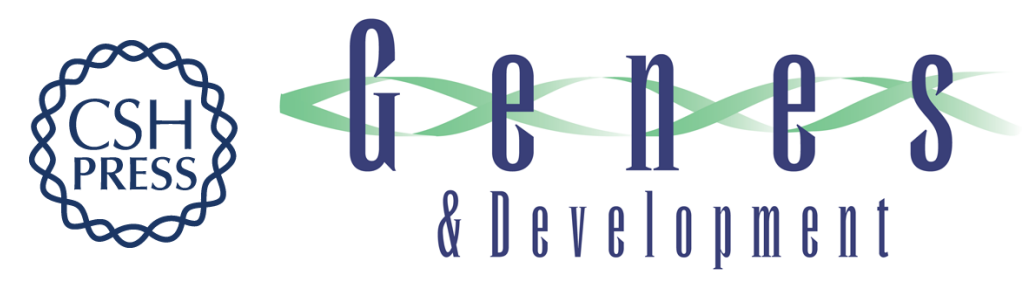

\section{Unlocking epigenetic codes in neurogenesis}

Bing Yao and Peng Jin

Genes Dev. 2014, 28:

Access the most recent version at doi:10.1101/gad.241547.114

References This article cites 248 articles, 55 of which can be accessed free at: http://genesdev.cshlp.org/content/28/12/1253.full.html\#ref-list-1

Creative This article is distributed exclusively by Cold Spring Harbor Laboratory Press for the first Commons six months after the full-issue publication date (see License http://genesdev.cshlp.org/site/misc/terms.xhtml). After six months, it is available under a Creative Commons License (Attribution-NonCommercial 4.0 International), as described at http://creativecommons.org/licenses/by-nc/4.0/.

Email Alerting Receive free email alerts when new articles cite this article - sign up in the box at the top Service right corner of the article or click here.

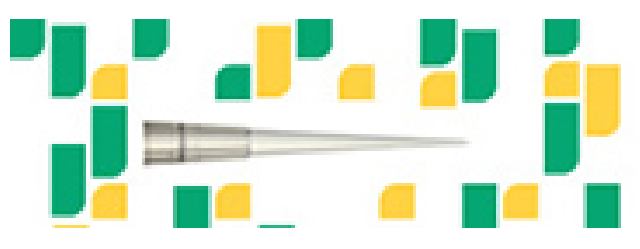

Focused on your science. 